\title{
Light-Evoked Calcium Responses of Isolated Melanopsin- Expressing Retinal Ganglion Cells
}

\author{
Andrew T. E. Hartwick, ${ }^{1}$ Jayne R. Bramley, ${ }^{1}$ Jianing Yu, ${ }^{2}$ Kelly T. Stevens, ${ }^{2}$ Charles N. Allen, ${ }^{3}$ William H. Baldridge, ${ }^{2}$ \\ Patricia J. Sollars, ${ }^{1}$ and Gary E. Pickard ${ }^{1}$ \\ ${ }^{1}$ Biomedical Sciences, Colorado State University, Fort Collins, Colorado 80523, ${ }^{2}$ Anatomy and Neurobiology, Ophthalmology and Visual Sciences, Dalhousie \\ University, Halifax, Nova Scotia, Canada B3H 1X5, and ${ }^{3}$ Center for Research on Occupational and Environmental Toxicology, Oregon Health and Science \\ University, Portland, Oregon 97239
}

A small number $(<2 \%)$ of mammalian retinal ganglion cells express the photopigment melanopsin and are intrinsically photosensitive (ipRGCs). Light depolarizes ipRGCs and increases intracellular calcium levels $\left(\left[\mathrm{Ca}^{2+}\right]_{\mathrm{i}}\right)$ but the signaling cascades underlying these responses have yet to be elucidated. To facilitate physiological studies on these rare photoreceptors, highly enriched ipRGC cultures from neonatal rats were generated using anti-melanopsin-mediated plate adhesion (immunopanning). This novel approach enabled experiments on isolated ipRGCs, eliminating the potential confounding influence of rod/cone-driven input. Light induced a rise in $\left[\mathrm{Ca}^{2+}\right]_{\mathrm{i}}$ (monitored using fura-2 imaging) in the immunopanned ipRGCs and the source of this $\mathrm{Ca}^{2+}$ signal was investigated. $\mathrm{The} \mathrm{Ca}^{2+}$ responses were inhibited by 2-aminoethoxydiphenyl borate, SKF-96365 (1-2-(4-methoxyphenyl)-2-[3-(4-methoxyphenyl)propoxy]ethyl-1Himidazole), flufenamic acid, lanthanum, and gadolinium, consistent with the involvement of canonical transient receptor potential (TRP) channels in ipRGC phototransduction. However, the contribution of direct $\mathrm{Ca}^{2+}$ flux through a putative TRP channel to ipRGC $\left[\mathrm{Ca}^{2+}\right]_{\mathrm{i}}$ was relatively small, as most $(\sim 90 \%)$ of the light-induced $\mathrm{Ca}^{2+}$ responses could be blocked by preventing action potential firing with tetrodotoxin. The L-type voltage-gated $\mathrm{Ca}^{2+}$ channel (VGCC) blockers verapamil and (+)-cis-diltiazem significantly reduced the lightevoked $\mathrm{Ca}^{2+}$ responses, while the internal $\mathrm{Ca}^{2+}$ stores depleting agent thapsigargin had negligible effect. These results indicate that $\mathrm{Ca}^{2+}$ influx through VGCCs, activated after action potential firing, was the primary source for light-evoked elevations in ipRGC $\left[\mathrm{Ca}^{2+}\right]_{\mathrm{i}}$. Furthermore, concurrent $\mathrm{Ca}^{2+}$ imaging and cell-attached electrophysiological recordings demonstrated that the $\mathrm{Ca}^{2+}$ responses were highly correlated to spike frequency, thereby establishing a direct link between action potential firing and somatic $\left[\mathrm{Ca}^{2+}\right]_{\mathrm{i}}$ in lightstimulated ipRGCs.

Key words: retinal ganglion cell; melanopsin; calcium; TRP channel; voltage-gated calcium channels; circadian rhythms

\section{Introduction}

In addition to rod and cone photoreceptors, a third photoreceptor class in the mammalian retina has been revealed with the discovery of intrinsically photosensitive retinal ganglion cells (ipRGCs) that express the photopigment melanopsin (Berson et al., 2002; Hattar et al., 2002). These rare neurons, comprising $<2 \%$ of the overall RGC population in mammals (Hattar et al., 2002; Morin et al., 2003; Sollars et al., 2003; Dacey et al., 2005), send axons to several retinorecipient structures with particularly dense innervation occurring in the hypothalamic suprachiasmatic nucleus $(\mathrm{SCN})$ and the olivary pretectal nucleus (OPN)

Received Aug. 9, 2007; revised Sept. 26, 2007; accepted 0ct. 22, 2007.

This work was supported by National Institutes of Health Grants MH062296, EY017809 (G.E.P., P.J.S.), and MH070922 (C.N.A.), Canadian Institutes of Health Research (CIHR) Grant MOP-15683, and Group grant in the Retina (W.H.B.). A.T.E.H. was supported by a CIHR postdoctoral fellowship and J.Y. was supported by a Nova Scotia Health Research Foundation studentship. Pilot studies were performed by A.T.E.H. during a summer fellowship, supported by the Grass Foundation at the Marine Biological Laboratory in Woods Hole, MA. We thank Connie King and Anne Simpson for assistance with animal care.

Correspondence should be addressed to Gary E. Pickard at the above address. E-mail: gpickard@lamar.colostate.edu.

D0I:10.1523/JNEUROSCI.3626-07.2007

Copyright $\odot 2007$ Society for Neuroscience $\quad$ 0270-6474/07/2713468-13\$15.00/0
(Gooley et al., 2003; Hannibal and Fahrenkrug, 2004a; Hattar et al., 2006). The SCN is the primary circadian oscillator responsible for the generation of circadian rhythms and retinal input entrains the SCN clock to the day/night cycle; the OPN mediates the pupillary light reflex. Functional analyses have confirmed that ipRGCs contribute photic information to these nonvisual systems (Hattar et al., 2003; Panda et al., 2003).

Unlike the hyperpolarizing light responses of rods and cones, light depolarizes ipRGCs and induces action potential firing (Berson et al., 2002; Warren et al., 2003; Dacey et al., 2005). The membrane channel that carries the initial inward current has not been conclusively identified, although there is pharmacological evidence that supports the involvement of a canonical transient receptor potential (TRPC) channel (Warren et al., 2006; Sekaran et al., 2007). Because mammalian TRPC channels are homologous to the TRP and TRP-like channels that mediate the lightactivated depolarizing responses of Drosophila photoreceptors (Minke and Parnas, 2006; Ramsey et al., 2006), these studies lend support to the hypothesis that melanopsin-related phototransduction may share a number of characteristics common to invertebrate light signaling pathways (Peirson and Foster, 2006; Berson, 2007). A hallmark of Drosophila TRP and TRP-like channels 
is a high permeability to $\mathrm{Ca}^{2+}$ (Reuss et al., 1997), and consistent with the putative similarities between mammalian ipRGCs and Drosophila photoreceptors, it has been reported that light stimulates an increase in the intracellular $\mathrm{Ca}^{2+}$ concentration $\left(\left[\mathrm{Ca}^{2+}\right]_{\mathrm{i}}\right)$ in ipRGC somata (Sekaran et al., 2003, 2005).

However, it has yet to be determined whether ipRGC $\mathrm{Ca}^{2+}$ responses result primarily from the direct flux of this cation through the light-gated channel (such as a TRPC channel). Alternatively, the light-induced changes in ipRGC $\left[\mathrm{Ca}^{2+}\right]_{\mathrm{i}}$ could also be influenced by either $\mathrm{Ca}^{2+}$ influx through voltage-gated $\mathrm{Ca}^{2+}$ channels (VGCCs) or the release of $\mathrm{Ca}^{2+}$ from internal stores. The goal of this work, therefore, was to characterize the source of the light-activated $\mathrm{Ca}^{2+}$ signals in ipRGCs and to determine the relationship of these responses to light-driven action potential firing. To address these questions, we successfully generated highly enriched cultures of melanopsin-expressing ipRGCs from neonatal rats and recorded light responses from these isolated neurons through $\mathrm{Ca}^{2+}$ imaging, both alone and in conjunction with cell-attached electrophysiological recordings.

\section{Materials and Methods}

Immunopanned RGC cultures. All experiments were approved by the Colorado State University Animal Care and Use Committee. Unless noted otherwise, chemicals and reagents were obtained from Sigma (St. Louis, MO). Long-Evans rats (4-6 per session) were killed on postnatal day 5 (P5)-P7 by halothane overexposure and decapitation. At this neonatal age, rat (Hannibal and Fahrenkrug, 2004b) and mouse (Sekaran et al., 2005) ipRGCs have been shown previously to be light responsive. After enucleation, the retinas were dissected in Hibernate-A medium (BrainBits, Springfield, IL) with 2\% B27 supplements (Invitrogen, Carlsbad, CA) and $10 \mu \mathrm{g} / \mathrm{ml}$ gentamicin. The retinas were then incubated for $30 \mathrm{~min}$ at $37^{\circ} \mathrm{C}$ in $10 \mathrm{ml} \mathrm{Ca}{ }^{2+} / \mathrm{Mg}^{2+}$-free Dulbecco's PBS (DPBS; Invitrogen) containing $165 \mathrm{U}$ of papain (Worthington Biochemicals, Lakewood, NJ), $1 \mathrm{~mm}$ L-cysteine, and $0.004 \%$ DNase, and then mechanically triturated in an enzyme inhibitor solution of DPBS (with $\mathrm{Ca}^{2+}$ and $\mathrm{Mg}^{2+}$ ) containing $1.5 \mathrm{mg} / \mathrm{ml}$ ovomucoid (Roche Diagnostics, Indianapolis, IN), $1.5 \mathrm{mg} / \mathrm{ml}$ bovine serum albumin (BSA), and $0.004 \%$ DNase. The suspension was centrifuged ( $200 \mathrm{~g}$ for $11 \mathrm{~min}$ ) and washed in DPBS containing higher concentrations $(10 \mathrm{mg} / \mathrm{ml})$ of ovomucoid and BSA. After spinning down again, the cells were resuspended in a panning buffer of DPBS containing $0.2 \mathrm{mg} / \mathrm{ml} \mathrm{BSA}$ and $5 \mu \mathrm{g} / \mathrm{ml}$ insulin and passed through a $20 \mu \mathrm{m}$ Nitex mesh (Sefar Filtration, Depew, NY) to minimize cell clumping.

We used a melanopsin-antibody panning protocol that was modified from the Thyl-based RGC panning method originally developed by Barres et al. (1988). The dissociated cells were incubated sequentially for $20 \mathrm{~min}$ on two $150 \mathrm{~mm}$ Petri dishes precoated the night before with Griffonia (Bandeiraea) simplicifolia lectin I (0.2 mg in $24 \mathrm{ml} 50 \mathrm{~mm}$ Tris $\mathrm{HCl}, \mathrm{pH}$ 9.5; Vector Laboratories, Burlingame, CA). This lectin panning step helped to eliminate contaminating cells such as macrophages and microglia, which tend to bind nonspecifically to any antibody-coated panning plate. The remaining cell suspension was incubated for $20 \mathrm{~min}$ (at room temperature) with extra BSA $(5-6 \mathrm{mg} / \mathrm{ml}$ final concentration) and rabbit anti-rat $\mathrm{N}$ terminus melanopsin antibodies (1:300 dilution; \#JHU-71; ATCC, Manassas, VA; deposited by K. Yau, Johns Hopkins University, Baltimore, MD) (Hattar et al., 2002). The solution was then centrifuged at $200 \mathrm{~g}$ for $11 \mathrm{~min}$ and, after supernatant removal, the cells were resuspended in panning buffer, passed through the $20 \mu \mathrm{m}$ Nitex mesh, and placed on a $100 \mathrm{~mm}$ Petri dish precoated with goat anti-rabbit IgG (heavy and light chains) antibodies (Jackson ImmunoResearch, West Grove, PA). After $30 \mathrm{~min}$, the dish was repeatedly rinsed with DPBS and remaining adherent cells were incubated in $0.125 \%$ trypsin solution for $8 \mathrm{~min}$ at $37^{\circ} \mathrm{C}$ and then released from the plate by manually pipetting an enzyme inhibitor solution (30\% fetal bovine serum in Neurobasal-A medium) along the dish surface. These melanopsin-panned cells were plated into one or two wells containing a poly-D-lysine/laminin-coated Biocoat glass coverslip (12 mm; BD Biosciences, San Diego, CA) and 750 $\mu l$ of culture medium consisting of Neurobasal-A plus 2\% B27 supplements, and $1 \mathrm{~mm}$ glutamine (all from Invitrogen), with $25 \mathrm{ng} / \mathrm{ml} \mathrm{BDNF}$, $10 \mathrm{ng} / \mathrm{ml} \mathrm{CNTF}, 5 \mu \mathrm{M}$ forskolin, and $10 \mu \mathrm{g} / \mathrm{ml}$ gentamicin. Each coverslip was cut into 6-12 pieces with a diamond-tipped knife to enable more experiments on cells cultured together in one well. Cultures were maintained in the dark at $37^{\circ} \mathrm{C}$ in a humidified $5 \% \mathrm{CO}_{2}$-air atmosphere.

In some experiments, the suspension of nonadherent cells remaining after the melanopsin panning step were further incubated on another dish that had been first coated with goat anti-mouse IgM ( $\mu$ chain) antibodies (Jackson ImmunoResearch) and second with anti-Thyl.1 monoclonal IgM antibodies (generated from T11D7e2 hybridoma cell line; ATCC). These Thy1-panned RGCs were released from the plate and cultured as described above. Additional details on the generation of conventional RGC cultures with Thyl-immunopanning are described previously (Barres et al., 1988; Meyer-Franke et al., 1995; Hartwick et al., 2004).

Immunocytochemistry. The cultured cells were rinsed with $0.1 \mathrm{M}$ PBS and fixed for $10 \mathrm{~min}$ in $4 \%$ paraformaldehyde in PBS. The cells were washed three times with PBS and then kept for $30 \mathrm{~min}$ in a serum blocking solution consisting of $50 \%$ goat serum, $50 \%$ buffer solution, and $0.1 \%$ Triton X-100. The buffer solution contained $150 \mathrm{~mm} \mathrm{NaCl}, 50 \mathrm{~mm}$ Tris base, $1 \%$ BSA, $100 \mathrm{~mm}$ L-lysine, and $0.04 \%$ sodium azide in distilled water, $\mathrm{pH}$ 7.4. After the blocking step, the cells were incubated overnight at room temperature with rabbit anti-rat melanopsin (C terminus) antibodies diluted 1:10,000 in the buffer solution. The melanopsin antibodies were generously donated by R. Lane Brown (Washington State University, Pullman, WA) (Warren et al., 2006). In double-labeling experiments for melanopsin and Thyl, mouse anti-rat Thy1 (CD90) antibodies (1:1000; BD Biosciencs, San Diego, CA) were included for the overnight incubation. The following day, the cells were rinsed with PBS and incubated for $30 \mathrm{~min}$ in secondary antibodies (Alexa Fluor 594 goat anti-rabbit IgG and Alexa Fluor 488 goat anti-mouse IgG; Invitrogen) diluted 1:500 in the buffer solution, and then mounted in Vectashield (Vector Laboratories) on glass slides. In quantification experiments, the percentage of melanopsin-positive cells were counted on two to three coverslip pieces for a given culture. Slides were examined using a Leica (Wetzler, Germany) DMRA light microscope equipped with epifluorescence. The cells were illuminated using a dual-band filter set (catalog \#51019, EGFP/dsRED; Chroma Technology, Rockingham, VT).

Reverse transcriptase-PCR. Total RNA was extracted from melanopsinand Thyl-panned cells using Trizol reagent (Invitrogen) according to manufacturer's instructions. After DNA digestion (RQ1 RNase-free DNase; Promega, Madison, WI), total RNA was reverse transcribed using random primers, oligo(dt)12-18 (GE Healthcare, Piscataway, NJ), and moloney murine leukemia virus reverse transcriptase (RT) (Promega).

Primers for amplification of melanopsin were $5^{\prime}$-GCTGTCTTTGGCATCGTTTC-3' (sense) and 5'-AATGAGCAGAGGGAGGAAGAAG-3' (antisense) (300 bp fragment), designed against the rat melanopsin sequence (GenBank accession number AY072689). TRPC channel primers were as follows: TRPC3, 5'-GCCCAACATCACCGTTATTG-3' (sense) and 5'-GAAGGCAGCAATGAAGATGGAG-3' (antisense) (211 bp fragment); TRPC6, 5'-GAAGTCACGAAGACCTTTC-3' (sense) and 5' -TGGCTCTAACGACAGTCTC-3' (antisense) (332 bp fragment); and TRPC7, 5'-ACCTGACAGCCAATAGCAC-3' (sense) and 5' -TCCCAAACTTCTCGCTGAG-3' (antisense) (240 bp fragment). GenBank accession numbers were NM_021771, NM_013838, and NM_012035 for TRPC3, C6, and C7, respectively.

For melanopsin, PCR conditions included initial denaturation at $94^{\circ} \mathrm{C}$ for $3 \mathrm{~min}, 35 \mathrm{cycles}$ of denaturation at $94^{\circ} \mathrm{C}$ for $30 \mathrm{~s}$, annealing at $59^{\circ} \mathrm{C}$ for $1 \mathrm{~min}$, and extension at $72^{\circ} \mathrm{C}$ for $1 \mathrm{~min}$, followed by final extension at $72^{\circ} \mathrm{C}$ for $10 \mathrm{~min}$, run on a $1 \%$ gel. For TRPC, conditions included initial denaturation at $94^{\circ} \mathrm{C}$ for $1 \mathrm{~min}, 40$ cycles of denaturation at $94^{\circ} \mathrm{C}$ for $30 \mathrm{~s}$, annealing at $61.8^{\circ} \mathrm{C}$ (TRPC3) or $52.0^{\circ} \mathrm{C}$ (TRPC6 and C7) for $1 \mathrm{~min}$, and extension at $72^{\circ} \mathrm{C}$ for $1 \mathrm{~min}$, followed by final extension at $72^{\circ} \mathrm{C}$ for 10 $\mathrm{min}$, run on a $1.5 \%$ gel. Cyclophilin conditions were initial denaturation at $94^{\circ} \mathrm{C}$ for $1 \mathrm{~min}, 26$ cycles of denaturation at $94^{\circ} \mathrm{C}$ for $30 \mathrm{~s}$, annealing at $50^{\circ} \mathrm{C}$ for $30 \mathrm{~s}$, and extension at $72^{\circ} \mathrm{C}$ for $1 \mathrm{~min}$, followed by final extension at $72^{\circ} \mathrm{C}$ for $10 \mathrm{~min}$, run on a $1 \%$ gel. PCR products were visualized on agarose gel containing ethidium bromide using Edas 290 and 1D (Kodak, 
Rochester, NY) software and band optical density was quantified with Scion (Frederick, MD) Image software.

Calcium imaging. After $1-3 \mathrm{~d}$ in culture, the coverslip-plated melanopsin-panned cells were removed from the incubator under dim red light and transferred to modified HBSS (15 mM HEPES, $2.6 \mathrm{~mm}$ $\mathrm{CaCl}_{2}, \mathrm{Mg}^{2+}$-free, $\mathrm{pH} 7.4$ ) containing $0.1 \%$ pluronic acid $\mathrm{F}-127$ and 5 $\mu \mathrm{M}$ fura-2 $\mathrm{AM}$ (Invitrogen) $\mathrm{Ca}^{2+}$ indicator dye for $30 \mathrm{~min}$ in the dark at $37^{\circ} \mathrm{C}$. The fura-loaded cells were then transferred (under dim red light) to the microscope chamber (model RC-26GLP; Warner Instruments, Hamden, CT) that was constantly superfused with HBSS warmed to $33-35^{\circ} \mathrm{C}$ (using SF-28 inline heater; Warner Instruments) and bubbled with 100\% oxygen. All tested drugs were dissolved in the HBSS and delivered to the chamber by a peristaltic pump at a rate of $\sim 1 \mathrm{ml} / \mathrm{min}$. 2-aminoethoxydiphenyl borate, flufenamic acid, and thapsigargin were first dissolved in dimethyl sulfoxide (DMSO) as $1000 \times$ stock solutions, with control experiments confirming that $0.1 \%$ DMSO alone did not affect ipRGC light responses. To prevent precipitation of the lanthanides, potassium phosphate, and sodium phosphate was omitted from the HBSS used in imaging experiments testing $\mathrm{La}^{3+}$ and $\mathrm{Gd}^{3+}$.

The $\mathrm{Ca}^{2+}$ imaging methodology was similar to that in previous work on Thy1-panned RGCs (Hartwick et al., 2004). A 100 W mercury lamp and the appropriate filters (set 71000a, excitation 340 and $380 \mathrm{~nm}$; emission $510 \mathrm{~nm}$; Chroma Technology) were used to generate fura-2 fluorescence. A filter wheel (Empix Imaging, Cheektowaga, NY) alternated the 340 and $380 \mathrm{~nm}$ filters with excitation period for each wavelength set at $400 \mathrm{~ms}$. Fluorescence images (12 bit) were captured with a cooled charged-coupled device camera (Sensicam; Cooke, Romulus, MI) fitted to the upright microscope (Axioskop 2 FS; Carl Zeiss, Oberkochen, Germany) using a water-immersion objective (numerical aperture, $0.80 \mathrm{~W}$; Achroplan 40×; Zeiss). The images of RGC fluorescence at 340 and 380 $\mathrm{nm}$ excitation were calculated over a large area of the RGC soma and converted to ratiometric $(340 / 380 \mathrm{~nm})$ images by imaging software (Imaging Workbench 2.2; (Indec BioSystems, Santa Clara, CA). The background fluorescence was measured from an empty region on the coverslip and subtracted from each image.

To estimate the magnitude of the light-evoked $\mathrm{Ca}^{2+}$ responses, the fura-2 ratios $(R)$ in some experiments were converted to $\left[\mathrm{Ca}^{2+}\right]_{\mathrm{i}}$ using the formula $\left[\mathrm{Ca}^{2+}\right]_{\mathrm{i}}=K_{d}\left(F_{o} / F_{\mathrm{s}}\right)\left[\left(R-R_{\min }\right) /\left(R_{\max }-R\right)\right]$, with a $K_{d}$ for fura- $2=224 \mathrm{nM}$, and where $F_{o} / F_{s}$ is the ratio of fluorescence intensity at $380 \mathrm{~nm}$ excitation in $\mathrm{Ca}^{2+}$-free solution over the intensity in solution with saturating $\mathrm{Ca}^{2+}$ levels (Kao, 1994). A sample $(n=9)$ of ipRGCs were superfused first with $\mathrm{Ca}^{2+}$-free HBSS ( $10 \mathrm{~mm} \mathrm{Mg}{ }^{2+}, 2$ mM BAPTA, $10 \mu \mathrm{M}$ ionomycin) to determine the minimum value for the fura- 2 ratio $\left(R_{\min }\right)$, and then with saturating $\mathrm{Ca}^{2+}$ solution $(0.9 \%$ saline with $20 \mathrm{~mm}$ $\mathrm{Ca}^{2+}, 10 \mu \mathrm{M}$ ionomycin) to determine the maximum fura-2 ratio $\left(R_{\max }\right)$. Mean values for $F_{\mathrm{o}} / F_{\mathrm{s}}, R_{\min }$, and $R_{\max }$ were calculated from these ipRGCs.

To minimize the intensity of the fura- 2 excitation wavelengths (and reduce potential ipRGC stimulation), $8 \times 8$ pixel binned images were acquired. With this increased binning, adequate fluorescence was attained after reducing the 340 and $380 \mathrm{~nm}$ excitation intensities with -0.5 and $-2.5 \log$ neutral density filters, respectively. Light responses were calculated as the $\Delta$ fura- 2 ratio, the peak minus baseline fura- 2 ratio. The baseline was calculated as the average fura- 2 ratio of the three ratios acquired before light exposure, and the peak was the maximum fura- 2 ratio observed in the $100 \mathrm{~s}$ after light offset. Light-responding cells were defined as those exhibiting a rise in the fura- 2 ratio $>20 \%$ from baseline.

The stimulating light consisted of broad-spectrum light from a $100 \mathrm{~W}$ halogen bulb that passed through the condenser underneath the microscope chamber. Before imaging, the coverslip-plated cells were dimly illuminated with this light source to locate and bring individual cells into focus. This also served as a useful selection strategy, as the dim light exposure increased $\left[\mathrm{Ca}^{2+}\right]_{\mathrm{i}}$ in light-responding cells. For experiments involving 20 or 30 s light stimuli, fura-2 images were acquired immediately before and after (but not during) the light pulses. For 4 min light stimuli, the halogen light source was blocked every $10 \mathrm{~s}$ (unless otherwise indicated) to allow for the acquisition of fura-2 images. In initial experiments, light stimulation was controlled manually by uncovering and covering the light source with a black occluder, whereas in later experi- ments (including those using 4 min light exposures) it was remotely controlled by an electronic shutter (Uniblitz, Rochester, NY). To determine light intensity, the light stimulus was filtered through different narrow-band filters $(420,480,540$, and $600 \mathrm{~nm})$ plus an infrared light cutoff filter (all filters from Edmund Optics, Barrington, NJ), and a light detector (VISD; World Precision Instruments, Sarasota, FL) was placed in the approximate plane of the microscope chamber. The standard light stimulus used was measured as $2.0 \times 10^{13}$ photons $/ \mathrm{s} / \mathrm{cm}^{2}$ at $420 \mathrm{~nm}$, $6.9 \times 10^{13}$ photons $/ \mathrm{s} / \mathrm{cm}^{2}$ at $480 \mathrm{~nm}, 1.7 \times 10^{14}$ photons $/ \mathrm{s} / \mathrm{cm}^{2}$ at 540 $\mathrm{nm}$, and $3.3 \times 10^{14}$ photons $/ \mathrm{s} / \mathrm{cm}^{2}$ at $600 \mathrm{~nm}$.

Electrophysiology. Patch electrodes were pulled (P-87 Flaming-Brown pipette puller; Sutter Instruments, Novato, CA) from borosilicate glass capillaries ( $1.65 \mathrm{~mm}$ outer diameter and $0.45 \mathrm{~mm}$ wall thickness; Garner Glass, Claremont, CA) and were fire polished to resistances of 4-5 M $\Omega$. For perforated patch-clamp recordings (amphotericin $\mathrm{B}$ technique), the extracellular superfusing solution included (in $\mathrm{mM}$ ) $130 \mathrm{NaCl}, 2.5 \mathrm{KCl}, 2$ $\mathrm{CaCl}_{2}, 1 \mathrm{MgCl}_{2}, 10 \mathrm{HEPES}$, and 10 glucose, with $\mathrm{pH}$ adjusted to 7.4 with $\mathrm{NaOH}$, and the intrapipette solution consisted of (in mм) 80 K-gluconate, $50 \mathrm{KCl}, 1 \mathrm{MgCl}_{2}, 10 \mathrm{HEPES}, 9 \mathrm{NaCl}$, and $0.2 \mathrm{EGTA}$, pH 7.4. Amphotericin B was prepared as a stock solution in DMSO at a concentration of $60 \mathrm{mg} / \mathrm{ml}$ on each experimental day. The pipette tip was first filled with intrapipette solution and then back-filled with same internal solution plus $240 \mu \mathrm{g} / \mathrm{ml}$ of amphotericin B. Phase-bright neurons were identified under dim light. After tight-seal formation $(>5 \mathrm{G} \Omega)$, the cell was maintained in the dark and the series resistance $(R \mathrm{~s})$ was continuously monitored by the capacitance current generated by $-5 \mathrm{mV}$ voltage steps. Rs usually dropped to $<20 \mathrm{M} \Omega$ in $15 \mathrm{~min}$. Light stimulation, using broad-spectrum light from the microscope halogen light source, occurred at least $20 \mathrm{~min}$ after seal formation. The cells were recorded in the current-clamp configuration using a MultiClamp 700A amplifier (Molecular Devices, Sunnyvale, CA) and digitized at $10 \mathrm{kHz}$. For figure illustration, data intervals were reduced to $1 \mathrm{~ms}$. Initial perforated patchclamp recordings (see Fig. $7 A$ ) were performed using a microscope rig not equipped with an inline heater, and were therefore obtained at room temperature $\left(\sim 25^{\circ} \mathrm{C}\right)$. Experiments involving concurrent $\mathrm{Ca}^{2+}$ imaging and perforated patch recordings (see Fig. $7 B$ ) were done using the microscope used for $\mathrm{Ca}^{2+}$ imaging described above, with the external solution warmed to $33-35^{\circ} \mathrm{C}$.

For cell-attached patch recordings, the extracellular solution was HBSS ( 15 mm HEPES, $2.6 \mathrm{~mm} \mathrm{CaCl}_{2}, 2.0 \mathrm{~mm} \mathrm{MgCl}_{2}, \mathrm{pH} 7.4$, warmed to $33-35^{\circ} \mathrm{C}$ ) and the pipette was filled with the same HBSS. The recordings were obtained with the acquisition software (pClamp 10; Molecular Devices) in voltage-clamp mode, although no holding potential was applied. The electrode tip was positioned above the target cell under dim light and then slowly lowered until a loose seal (100-500 $\mathrm{M} \Omega$ ) was formed. The cell was then maintained in the dark for 10-40 min, during which time the seal resistance would approach $1 \mathrm{G} \Omega$. We found this approach to be much more successful than using suction to establish an immediate tight seal. Suction generally induced a rise in ipRGC $\left[\mathrm{Ca}^{2+}\right]_{\mathrm{i}}$. Cells that did not recover fully from this elevation in $\left[\mathrm{Ca}^{2+}\right]_{\mathrm{i}}$ would not subsequently respond to light stimuli. By forming seals that were initially loose, using little to no suction, we found that the electrode-induced $\mathrm{Ca}^{2+}$ influx could be minimized and the cell-attached recordings of the ipRGC light responses were more successful. The cause of this $\mathrm{Ca}^{2+}$ influx is not yet known, but Leinders-Zufall et al. (1994) reported a similar phenomenon in their attempts to combine $\mathrm{Ca}^{2+}$ imaging with whole-cell patch-clamp recordings from nonphotosensitive RGCs cultured from neonatal rats.

\section{Results \\ Isolation of melanopsin-expressing ipRGCs by immunopanning}

It is well established that most, if not all, RGCs express the cellsurface protein Thyl and that highly purified RGC cultures can be produced using a Thyl-antibody-mediated plate adhesion (immunopanning) technique (Barres et al., 1988; Meyer-Franke et al., 1995). Because melanopsin is membrane-bound (Provencio et al., 1998), we modified the immunopanning method and 

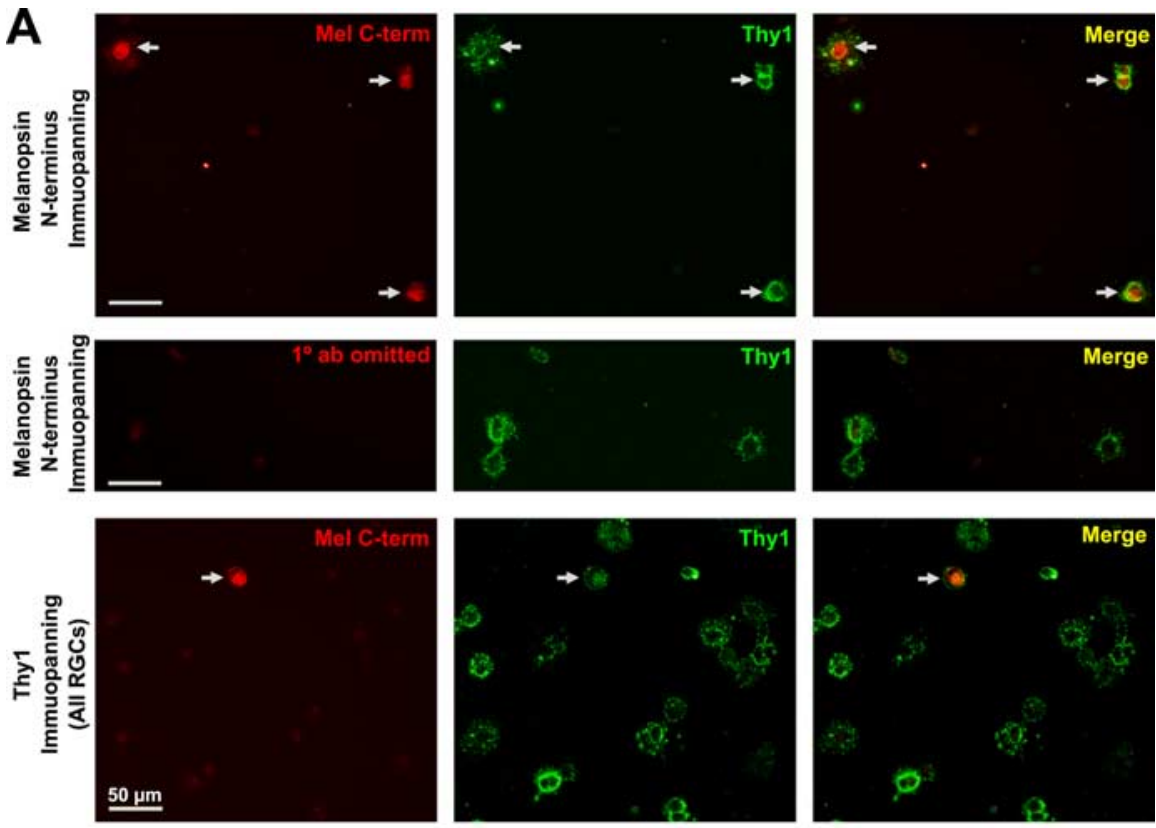

B
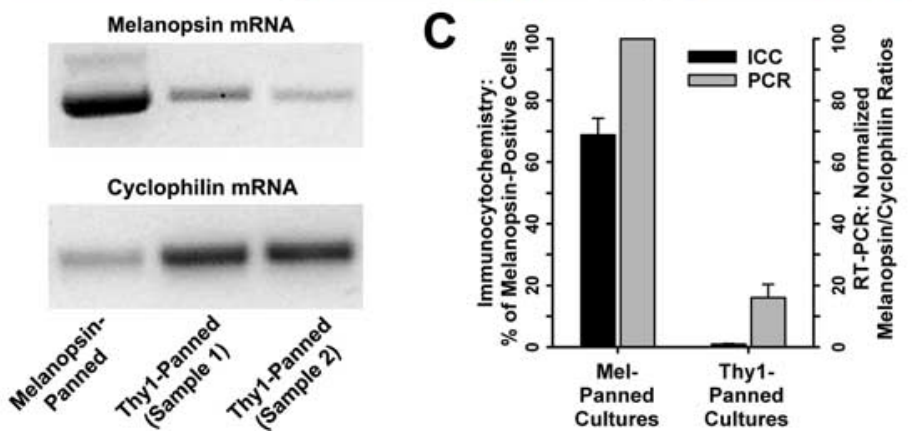

Figure 1. Enriched melanopsin-expressing RGC cultures. A, Top, Melanopsin-panned cells (denoted by arrows), paraformaldehyde-fixed on first day of culture, were labeled by antibodies targeting both the intracellular C terminus of melanopsin (red fluorescence) and the RGC cell-surface marker Thy1 (green fluorescence). Middle, To control for antibody specificity, melanopsin-panned cells from the same culture were processed identically except that primary melanopsin antibodies were omitted. Bottom, Thy1-panned cells obtained from the same rat litter (Thy1 panning followed melanopsin panning) and processed at the same time. Melanopsin-expressing RGCs were also present in Thy1-panned cultures (arrow) but were rare. $B, R T-P C R$ confirmed the presence of melanopsin mRNA in both melanopsin- and Thy1-panned cultures, with increased message relative to internal control cyclophilin detected in melanopsin-panned cultures. C, Summary graph (means \pm SEM) showing both the percentage of melanopsin-positive cells in melanopsin-panned and sibling Thy1-panned cultures from immunocytochemical cell counts (ICC; $n=5$ cultures), and the melanopsin to cyclophilin product optical density ratios for Thy1-panned samples $(n=4)$ that were normalized within each PCR experiment $(n=3)$ to that for melanopsin-panned samples.

used antibodies (Hattar et al., 2002) targeting the extracellular N terminus of melanopsin to specifically isolate rare melanopsinexpressing RGCs from dissociated neonatal rat retinas. To validate this methodology, the panned cells were fixed on the first day in vitro (DIV) and processed for immunocytochemistry using antibodies (Warren et al., 2006) raised against the intracellular C terminus of melanopsin (Fig. $1 \mathrm{~A}$, top, red fluorescence). On average, two-thirds (range, $50-82 \% ; n=5$ cultures) of the melanopsin-panned cells were immunoreactive for the intracellular melanopsin antigen (Fig. 1C). Omission of the melanopsin $\mathrm{C}$ terminus antibody resulted in no staining (Fig. $1 \mathrm{~A}$, middle, red fluorescence), controlling both for nonspecific fluorescence and for the possibility that the secondary antibodies were binding to residual $\mathrm{N}$ terminus antibodies remaining from the panning session. For comparison, melanopsin immunoreactivity was assessed on sibling cultures of Thyl-panned RGCs (Fig. 1 A, bottom, red fluorescence $)$ and a small number $(0.9 \pm 0.2 \%$ SEM $)$ of these cells were melanopsin-positive (Fig. 1C). The Thyl-panning step was performed on nonadherent cells that remained after the melanopsin-panning step, indicating that not every melanopsin-expressing RGC had been captured by melanopsin immunopanning. Also, melanopsin-positive cells in both cultures were immunoreactive for Thyl (Fig. $1 \mathrm{~A}$, green fluorescence), demonstrating that melanopsin-containing RGCs, like conventional RGCs, express Thyl.

To corroborate the immunocytochemical analysis, the presence of melanopsin in the immunopanned cultures was also evaluated using RT-PCR. As expected from the paucity of melanopsin RGCs in the rat retina (Hattar et al., 2002), the average yield of cells isolated by melanopsin-based panning, of $\sim 250-2000$ cells per dissociated retina, was much less than the yield of 25,000-40,000 cells per retina attained with Thyl-panning. Therefore, to obtain sufficient melanopsin-panned cell homogenate for RT-PCR, half of the cells from seven different panning sessions were pooled whereas the remainder were used for physiology experiments. "Thy1panned" samples were prepared from cells obtained from individual panning sessions. Even with this pooling, the smaller number of cells in the "melanopsinpanned" homogenate is reflected in the reduced message for cyclophilin relative to Thy1-panned samples (Fig. $1 B$ ). Normalizing to the cyclophilin mRNA product for each sample, the message for melanopsin was higher in the melanopsin-panned cultures compared with the Thyl-panned cultures (Fig. 1B,C). Together with the immunocytochemical findings, these results indicate that the melanopsin-based panning technique generated enriched cultures of melanopsin-expressing RGCs.

The light sensitivity of the isolated melanopsin-panned RGCs was next assessed using fura-2 $\mathrm{Ca}^{2+}$ imaging. A melanopsin-panned cell, with typical bilobed morphology, that responded to consecutive light stimuli is shown in Figure $2 A, B$ (cell 1). Fura-2 ratiometric images were acquired before and then immediately after the $20 \mathrm{~s}$ light stimulus. Photosensitivity was unique to the larger (soma diameter, $\geq 15 \mu \mathrm{m}$ ) "RGC-like" cells in the culture as light had no effect on the occasional smaller unidentified cell type (Fig. $2 A, B$, cell 2). These smaller cells served as negative controls, ruling out possible alterations in fura- 2 dye fluorescence by the light stimulus itself. To determine the repeatability of the light-stimulated $\mathrm{Ca}^{2+}$ signals, the melanopsin-panned cells were exposed to multiple light pulses with different time intervals $(5,10$, and $20 \mathrm{~min})$ between consecutive pulses (Fig. 2C,D). Of tested lightresponding cells, most ( 12 of 18 cells) continued to respond to the light stimuli regardless of the interstimulus interval. The remaining six cells exhibited negligible $\mathrm{Ca}^{2+}$ responses to light presented 

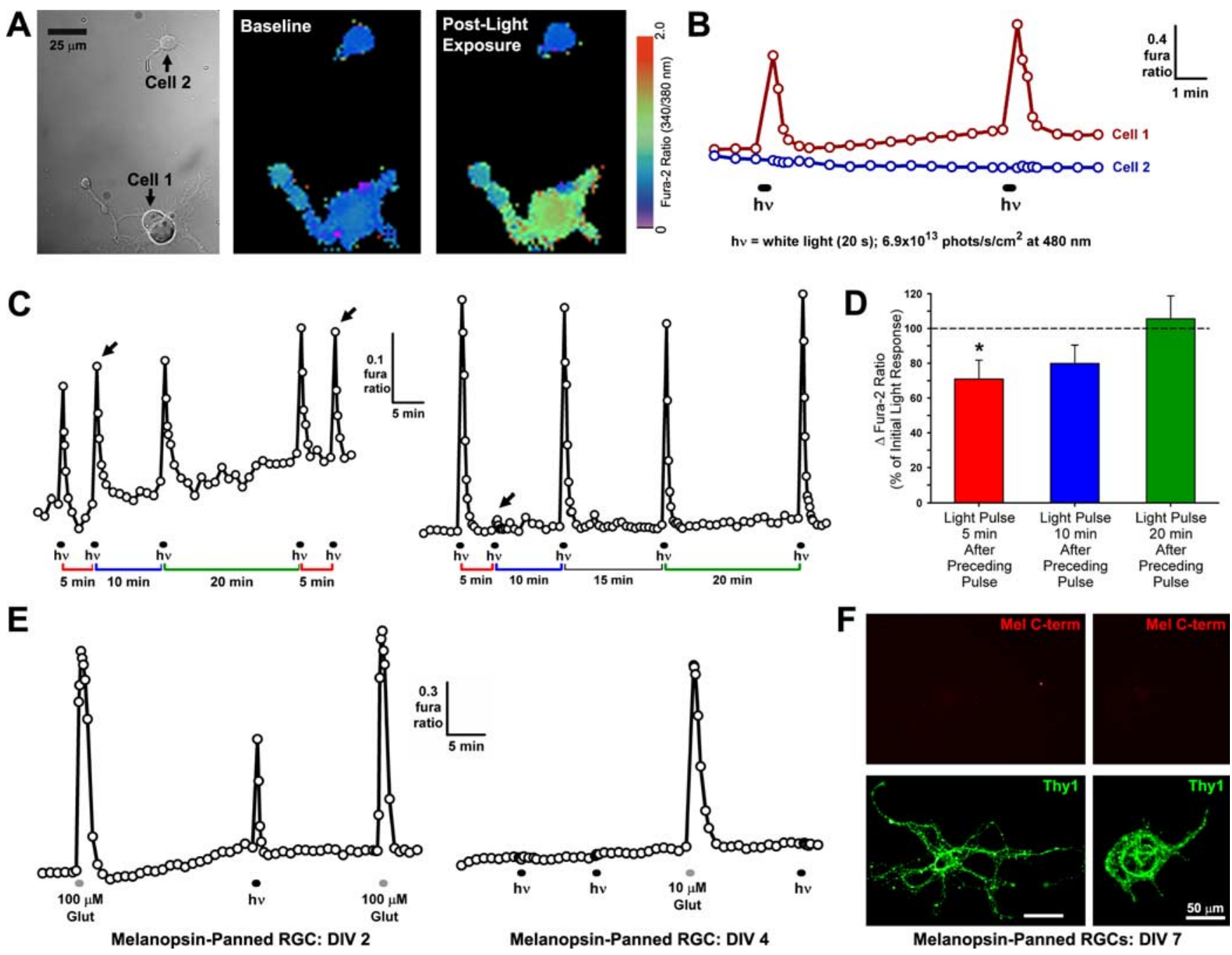

Figure 2. Photosensitivity of melanopsin-panned RGCs. A, Differential interference contrast image of two cells from a melanopsin-panned culture and pseudocolored images of fura- 2 fluorescence ratios for these cells before and after light stimulation. $\boldsymbol{B}$, The full optical recording for these cells showing that the larger melanopsin-panned RGC (cell 1 ) exhibited an increased fura-2 ratio (indicative of increased $\left[\mathrm{Ca}^{2+}\right]_{i}$ ) after each of two 20 s light pulses. The $\left[\mathrm{Ca}^{2+}\right]_{i}$ of the smaller "non-RGC-like" cell (cell 2) was unaffected by light. C, Multiple light responses could be elicited from the cultured cells (left trace), although some cells ( 6 of 18 cells) did not respond if the second stimulus was given 5 min after its preceding pulse (right trace; compare responses in two traces denoted by arrows). $\boldsymbol{D}$, Data summary shows effect (mean $\Delta$ fura- 2 ratio $\pm \mathrm{SEM} ; n=18 \mathrm{RGCS}$ ) of the interstimulus interval $\left(5,10\right.$, or $20 \mathrm{~min}$ ) on the $\mathrm{Ca}^{2+}$ signals evoked by 30 s light pulses (normalized to each ipRGC's initial light response; dashed line). ${ }^{*} p<0.05$, one-way repeated-measures ANOVA, Tukey's test, compared with responses elicited after 20 min intervals. $E$, Melanopsin-panned RGCS responded to both light and glutamate ( $30 \mathrm{~s}$ application) over the first few days in culture (recording on left from ipRGC on DIV 2), but their photosensitivity diminished with longer culture periods (recording on right from melanopsin-panned RGC on DIV 4). $\boldsymbol{F}$, Representative melanopsin-panned RGCs on DIV 7 that were immunoreactive for Thy1 (green; bottom row) but not melanopsin (red; top row). These cells were from the same culture as the DIV 1 melanopsin-panned RGCs depicted in Figure 1 ( (top row; note that Thy1-positive cells also melanopsin-positive), indicating that melanopsin protein expression had decreased.

5 min after the preceding pulse, with three of these recovering responsiveness after $10 \mathrm{~min}$, and two more recovering after a 20 min interval. Consequently, light pulses were spaced $>10 \mathrm{~min}$ apart in the subsequent pharmacological studies.

Although ipRGCs can directly respond to light stimulation, these photoreceptors also receive synaptic input from bipolar and amacrine cells within the retina (Belenky et al., 2003). The excitatory input is mediated by the neurotransmitter glutamate (Perez-Leon et al., 2006; Wong et al., 2007) and there is single-cell PCR data indicating that melanopsin-containing RGCs express NMDA-, kainate-, and AMPA-type glutamate receptor subunits (Jakobs et al., 2007). We confirmed the existence of functional glutamate receptors on ipRGCs as every light-responding cell that was challenged with glutamate $(n=24 ; 30 \mathrm{~s}$ application of 10-100 $\mu$ M glutamate) exhibited a $\mathrm{Ca}^{2+}$ response (Fig. 2E) similar to that previously reported for cultured RGCs (Hartwick et al., 2004, 2005).
Although light-evoked $\mathrm{Ca}^{2+}$ responses could be elicited from most of the isolated cells on the first day after panning (DIV 1), the proportion of cells retaining their photosensitivity decreased with each additional day in culture. This conclusion was based on the qualitative observation that it was harder to find light-responding cells using the pre-experiment selection method (see Materials and Methods). We have recorded definitive light responses in cells up to DIV 5, but responding ipRGCs were rare in cultures maintained for four or more days. This loss of photosensitivity was not likely caused by reduced viability, as the large melanopsin-panned cells of this in vitro age still responded to glutamate (Fig. 2E). Immunocytochemistry conducted on melanopsin-panned cells after 5-7 DIV $(n=3$ cultures) revealed large cells that were Thy1-positive but melanopsin-negative (Fig. 2F). Because the Thy-1-positive cells present in the melanopsin-panned cultures were also melanopsinimmunoreactive on the first day of culture (Fig. 1A), the most probable explanation for this finding is that there is a reduction in mela- 

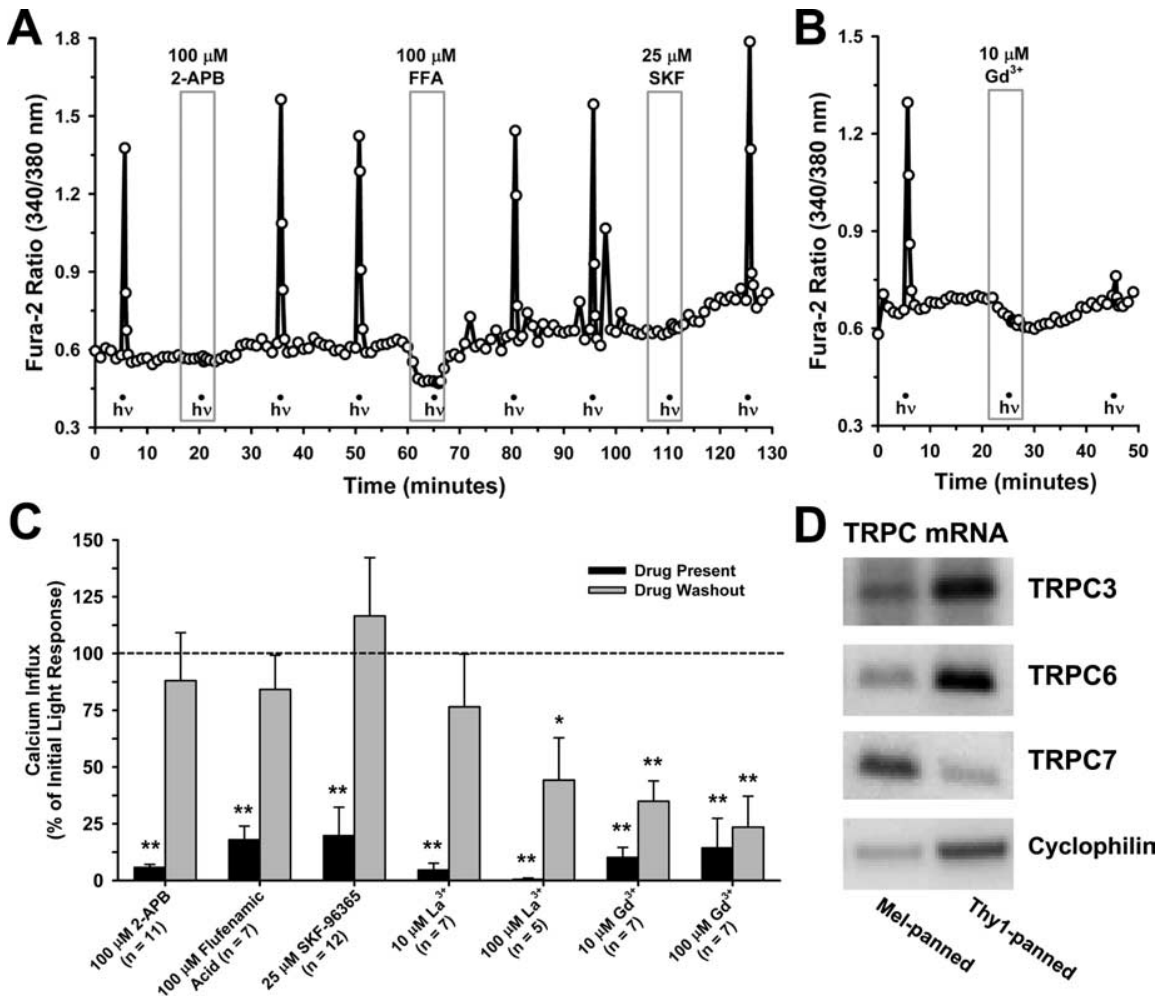

D TRPC mRNA

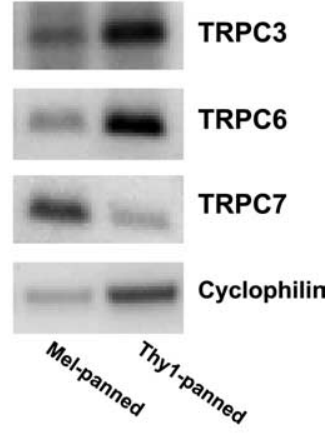

Figure 3. Evidence for TRPC channel involvement in ipRGC phototransduction. $\boldsymbol{A}$, Light-evoked $\mathrm{Ca}^{2+}$ signals were reversibly blocked by the TRPC blockers 2-APB, flufenamic acid (FFA), and SKF-96365 (SKF). The decrease in the baseline fura-2 ratio by FFA is attributable to its quenching effect on $340 \mathrm{~nm}$ excitation, and the data for this compound were analyzed nonratiometrically. $\boldsymbol{B}$, Fura-2 ratio trace from a cultured ipRGC in which $\mathrm{Gd}^{3+}$ inhibited the light response. $\mathrm{h} \nu$ indicates $20 \mathrm{~s}$ pulse of broad-spectrum light, $6.9 \times 10^{13}$ photons $/ \mathrm{s} / \mathrm{cm}^{2}$ at $480 \mathrm{~nm}$. C, Summary (means \pm SEM, normalized to each ipRGC's pretreatment response) showing effects of 2-APB, SKF, FFA, $\mathrm{La}^{3+}$, and $\mathrm{Gd}^{3+}$ on light-evoked $\mathrm{Ca}^{2+}$ influx. Except for the cell depicted in $\boldsymbol{A}$, one drug was assessed per cell. ${ }^{*} p<0.05$; $^{* *} p<0.01$, one-way repeated-measures ANOVA, Tukey's test, compared with initial responses. All responses in the presence of drugs were also significantly reduced $(p<0.05)$ compared with recovery (drug washout) responses, except for $100 \mu \mathrm{M} \mathrm{Gd}^{3+}$.D, RT-PCR for TRPC3, TRPC6, and TRPC7 mRNA in samples prepared from melanopsin-and Thy-1-panned cells. The TRPC7-to-cyclophilin ratio was elevated in the melanopsin-panned sample.

nopsin protein expression as the cells are cultured for longer periods. For this reason, all experiments presented in this work were performed on melanopsin-panned cells during the first $3 \mathrm{~d}$ of culture.

\section{Nature of light-evoked ipRGC $\mathrm{Ca}^{2+}$ responses}

A number of compounds recognized as nonselective TRPC channel blockers reduce the light-driven depolarization (Warren et al., 2006) and $\mathrm{Ca}^{2+}$ responses (Sekaran et al., 2007) of ipRGCs in whole-retina preparations dissected from rats and mice, respectively. We therefore sought to determine whether the lightevoked $\mathrm{Ca}^{2+}$ signals elicited in the dissociated rat ipRGCs displayed a similar pharmacological profile.

The light-induced $\mathrm{Ca}^{2+}$ responses of the isolated ipRGCs were reversibly reduced by 2-aminoethoxydiphenyl borate (2$\mathrm{APB})$,

1-2-(4-methoxyphenyl)-2-[3(4-methoxyphenyl)propoxy] ethyl-1 $H$-imidazole (SKF96365), and flufenamic acid (Fig. $3 A, C$ ), known blockers of many TRPC channels (Ramsey et al., 2006). The abrupt change in the fura- 2 ratio after the addition and washout of flufenamic acid was caused by its quenching effect on the 340 $\mathrm{nm}$ excitation light. Using a spectrophotometer (path length, $1 \mathrm{~cm})$, HBSS containing $100 \mu \mathrm{M}$ flufenamic acid was shown to exhibit an absorbance at $340 \mathrm{~nm}$ that was 5.8 times that of HBSS alone. Because the flufenamic acid solution did not absorb appreciably at $380 \mathrm{~nm}$ (absorbance 1.1 times that of
HBSS), the data for this compound were analyzed nonratiometrically using only the $380 \mathrm{~nm}$ excitation data (Fig. 3C). The flufenamic acid inhibition is consistent with TRPC3 or TRPC7, but not TRPC6 channels, as candidates, because this drug blocks TRPC3 and TRPC7 yet enhances TRPC6 activity (Inoue et al., 2001).

Lanthanum $\left(\mathrm{La}^{3+}\right)$ and gadolinium $\left(\mathrm{Gd}^{3+}\right)$ inhibit TRPC3 (Halaszovich et al., 2000), TRPC6 (Inoue et al., 2001) and TRPC7 channels (Riccio et al., 2002). Their action on TRPC4 and TRPC5 channels is more complex; at micromolar levels, $\mathrm{La}^{3+}$ and $\mathrm{Gd}^{3+}$ enhance current flow through TRPC4 or TRPC5 whereas higher (millimolar) concentrations inhibit these two channels (Schaefer et al., 2000; Jung et al., 2003). Application of either $\mathrm{La}^{3+}$ and $\mathrm{Gd}^{3+}$, at either 10 or $100 \mu \mathrm{M}$, abolished the light-stimulated $\mathrm{Ca}^{2+}$ influx in cultured ipRGCs (Fig. $3 B, C$ ), suggesting that TRPC4/5 channels were not involved. The reduced light-induced responses after treatment with $\mathrm{Gd}^{3+}$ and $100 \mu \mathrm{M} \mathrm{\textrm {La } ^ { 3 + }}$ was likely the result of a slower wash out of these trivalent cations.

We used RT-PCR to determine whether the isolated cells in the melanopsin-panned cultures expressed mRNA for TRPC3, TRPC6 or TRPC7 channels (Fig. 3D). For comparison, RTPCR was also performed on homogenate from conventional Thyl-panned RGC cultures. In two experiments, the TRPCto-cyclophilin ratios for TRPC3 and TRPC6 were similar for both melanopsinand Thy1-panned samples. As a semiquantitative analysis, the ratio for TRPC3 in the melanopsin-panned sample was 1.1 and 1.3 times that obtained for the Thy1-panned sample. Similarly, the ratio for TRPC6-to-cyclophilin in the melanopsin-panned sample was 0.9 and 1.1 times that obtained for the Thy1-panned sample. In contrast, TRPC7 was preferentially expressed in melanopsin-panned cultures, as its ratio was 2.8 and 5.7 times higher than that obtained for the Thyl-panned sample.

Both the RT-PCR results and the pharmacology of the lightevoked $\mathrm{Ca}^{2+}$ responses were consistent with the involvement of a TRPC channel, particularly TRPC7, in ipRGC phototransduction. However, rather than direct flux through a putative TRP channel, the source of the light-induced $\mathrm{Ca}^{2+}$ signal could instead be the result of $\mathrm{Ca}^{2+}$ release from intracellular stores, the activation of VGCCs, or a combination of these different mechanisms. Although the source of the $\mathrm{Ca}^{2+}$ signal was unknown in native ipRGCs, this issue has been investigated in human embryonic kidney (HEK) cells in which photosensitivity was conferred through melanopsin transfection (Kumbalasiri et al., 2007). In this heterologous expression system, the light-stimulated rise in $\left[\mathrm{Ca}^{2+}\right]_{\mathrm{i}}$ was shown to be entirely attributable to $\mathrm{Ca}^{2+}$ release from intracellular stores because (1) removal of extracellular $\mathrm{Ca}^{2+}$ did not alter the $\mathrm{Ca}^{2+}$ responses, (2) application of the stores depleting agent thapsigargin blocked the responses, and, in contrast to our work (Fig. $3 C$ ) and that of others that have as- 
sessed the effect of $\mathrm{La}^{3+}$ on ipRGC light responses (Warren et al., 2006; Sekaran et al., 2007), (3) the cation channel blocker $\mathrm{La}^{3+}$ was without significant effect (Kumbalasiri et al., 2007).

In an attempt to define the overall contribution of $\mathrm{Ca}^{2+}$ influx from the extracellular milieu, we first assessed whether $\mathrm{Ca}^{2+}$ responses could still be elicited from isolated ipRGCs bathed in $\mathrm{Ca}^{2+}$-free external solution containing the $\mathrm{Ca}^{2+}$ chelator BAPTA. With extracellular $\mathrm{Ca}^{2+}$ absent, the $\mathrm{Ca}^{2+}$ responses were completely abolished (Fig. 4A), as the mean change in the fura- 2 ratio ( $n=14$ ipRGCs) during light stimulation was only $1 \pm 1 \%$ SEM $(p<0.01$, one-way repeated-measures ANOVA, Tukey's test) of that first elicited from the ipRGCs during superfusion with $\mathrm{Ca}^{2+}$-containing HBSS. The light-evoked $\mathrm{Ca}^{2+}$ responses were recoverable after the cells' return to control HBSS (recovery responses were $90 \pm 18 \%$ SEM that of the initial responses). However, perfusing the cells with the $\mathrm{Ca}^{2+}$-free solution induced an unexpected abrupt rise in $\left[\mathrm{Ca}^{2+}\right]_{\mathrm{i}}$ before the expected decrease in $\left[\mathrm{Ca}^{2+}\right]_{\mathrm{i}}$ occurred (Fig. 4A). With the replenishment of external $\mathrm{Ca}^{2+}$ to the chamber, there was another transient rise of $\left[\mathrm{Ca}^{2+}\right]_{\mathrm{i}}$ that was reminiscent of store-operated $\mathrm{Ca}^{2+}$ entry, known to occur in many other cell types, in which stores depletion leads to the activation of plasma membrane $\mathrm{Ca}^{2+}$ channels to facilitate stores refilling (Lewis, 2007). Furthermore, application of $10 \mathrm{~mm}$ caffeine, a stimulator of $\mathrm{Ca}^{2+}$ release from endoplasmic reticulum (ER) $\mathrm{Ca}^{2+}$ stores (Verkhratsky, 2005), did not affect $\left[\mathrm{Ca}^{2+}\right]_{\mathrm{i}}$ in cells that had been switched to the $\mathrm{Ca}^{2+}$-free solution (Fig. 4B) (representative of $n=3$ ipRGCs), indicating that the internal stores had been depleted under these conditions. Thus, removal of external $\mathrm{Ca}^{2+}$ caused ipRGC internal stores to empty, and we could therefore not use this protocol to definitively distinguish between intracellular and extracellular sources for the lightevoked $\mathrm{Ca}^{2+}$ responses.

We next investigated the effect of thapsigargin, a compound that does not affect $\mathrm{Ca}^{2+}$ stores release directly but serves to gradually deplete $\mathrm{Ca}^{2+}$ stores by irreversibly inhibiting ER Ca ${ }^{2+}$ reuptake (Treiman et al., 1998). Thapsigargin itself did not alter ipRGC $\left[\mathrm{Ca}^{2+}\right]_{\mathrm{i}}$, consistent with a previous report that assessed this compound on $\left[\mathrm{Ca}^{2+}\right]_{\mathrm{i}}$ of isolated nonphotosensitive rat RGCs (Leinders-Zufall et al., 1994), signifying that there is minimal $\mathrm{Ca}^{2+}$ leak from ipRGC ER stores under basal conditions (Fig. 4C). In ipRGCs $(n=11)$ treated with thapsigargin $(1 \mu \mathrm{M}$; 5-30 min), there was no reduction ( $p>0.05$, one-way repeatedmeasures ANOVA, Tukey's test) in the $\mathrm{Ca}^{2+}$ responses either during treatment (response magnitude was $104 \pm 19 \%$ SEM of that elicited before treatment) or after washout (131 $\pm 27 \%$ SEM, relative to pretreatment responses) as would be expected if the stores had been emptying without the capacity to refill (Fig. 4C). In addition, light-evoked $\mathrm{Ca}^{2+}$ responses persisted in thapsigargin-treated ipRGCs that were exposed to caffeine (Fig. $4 D$ ) (representative of $n=3$ ipRGCs tested) to deplete stores more quickly. These results indicate that there was no significant contribution from internal $\mathrm{Ca}^{2+}$ stores to the light-stimulated $\mathrm{Ca}^{2+}$ responses of the isolated rat ipRGCs.

The lack of effect for thapsigargin on ipRGC $\mathrm{Ca}^{2+}$ dynamics differ from those (described above) reported by Kumbalasiri et al. (2007) using HEK cells transfected with melanopsin, suggesting that the mechanisms underlying phototransduction in heterologous systems may be different from that in native ipRGCs. Among the differences between HEK cells and ipRGCs is that the latter are excitable neurons. The depolarization associated with neuronal firing is known to activate VGCCs in neurons throughout the CNS, and so we subsequently probed the contribution of VGCCs to the light-induced rise in $\left[\mathrm{Ca}^{2+}\right]_{\mathrm{i}}$. Specifically, pharmacological agents targeting L-type $\left(\mathrm{Ca}_{\mathrm{V}} 1\right)$ and $\mathrm{N}$-type $\left(\mathrm{Ca}_{\mathrm{V}} 2.2\right)$ VGCCs were assessed because these VGCC types have been shown to carry the majority of the $\mathrm{Ca}^{2+}$ current in conventional rat RGCs (Karschin and Lipton, 1989; Schmid and Guenther, 1999). L-type VGCCs can be pharmacologically inhibited by phenylalkylamines such as verapamil, benzothiazepines like diltiazem, and dihydropyridines including nifedipine (Catterall et al., 2005). In preliminary experiments with nifedipine, we found that this yellowish compound absorbs asymmetrically at both the 340 and $380 \mathrm{~nm}$ excitation wavelengths. The differential quenching action of this compound on the two excitation wavelengths made it difficult to definitively separate true inhibition from artifact and, thus, verapamil and $(+)$-cis-diltiazem (these compounds 

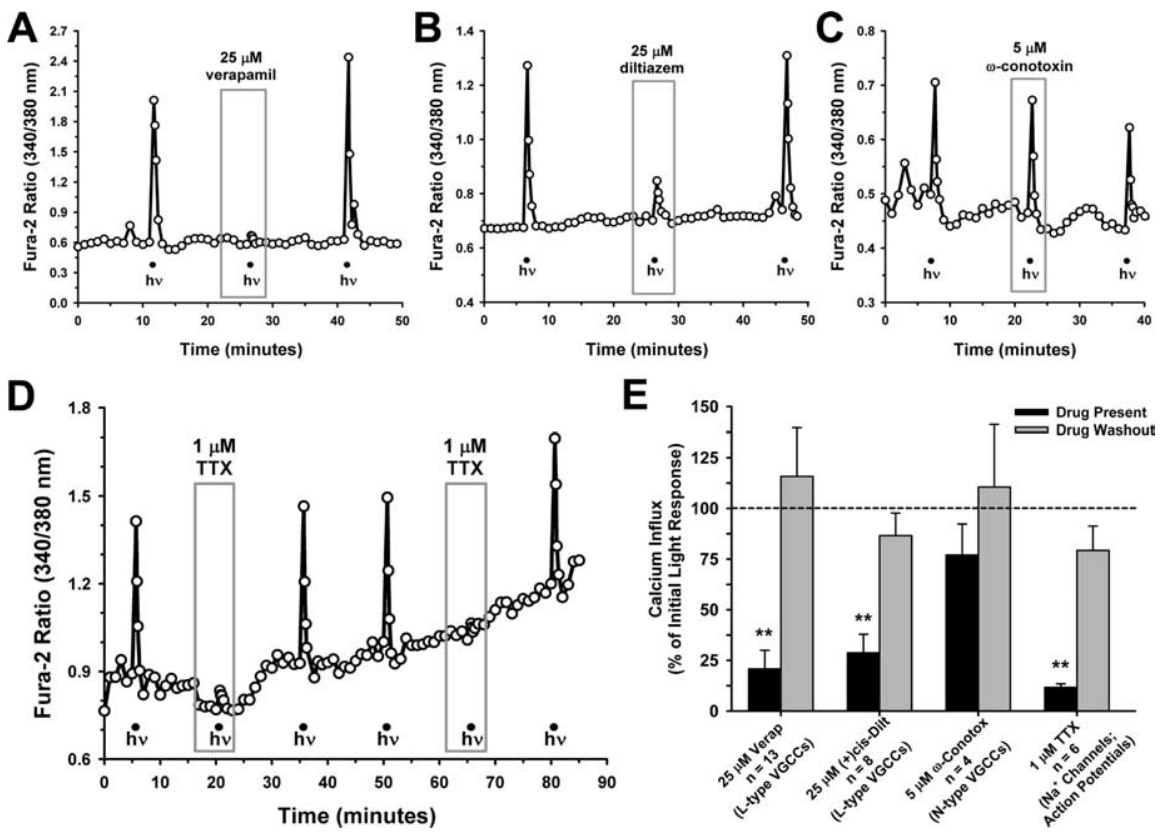

Figure 5. Primary source for the light-evoked $\mathrm{Ca}^{2+}$ signal is influx through L-type VGCCs. $\boldsymbol{A}, \boldsymbol{B}$, The L-type VGCC blockers verapamil $(\boldsymbol{A})$ and $(+)$-cis-diltiazem inhibited the ipRGC $\mathrm{Ca}^{2+}$ responses $(\boldsymbol{B})$. $\boldsymbol{C}$, The N-type VGCC blocker $\omega$-conotoxin GVIA was without significant effect. $\boldsymbol{D}$, Blockade of action potential firing with TTX also reversibly attenuated light-induced $\mathrm{Ca}^{2+}$ responses. For all traces, $h \nu$ indicates 20 s pulse of broad-spectrum light, $6.9 \times 10^{13}$ photons $/ \mathrm{s} / \mathrm{cm}^{2}$ at $480 \mathrm{~nm}$. $E$, Data summary (means \pm SEM, normalized to pretreatment responses). ${ }^{* *} p<0.01$, one-way repeated-measures ANOVA, Tukey's test, compared with initial and recovery responses.

did not alter fura-2 fluorescence) were used instead. Verapamil and diltiazem both significantly reduced (mean reduction of 79 and $71 \%$, respectively) the light-induced $\mathrm{Ca}^{2+}$ responses, and these effects were reversible with drug wash out (Fig. 5A,B,E). With the N-type VGCC blocker $\omega$-conotoxin GVIA present, $\mathrm{Ca}^{2+}$ responses were slightly reduced, on average, relative to the pretreatment responses (Fig. $5 C, E$ ), but this effect was not statistically significant $(p=0.40$; one-way repeated-measures ANOVA). Finally, to investigate a potential link between VGCC activation and action potential firing, we tested the effect of tetrodotoxin (TTX) which prevents action potential generation by blocking voltage-gated $\mathrm{Na}^{+}$channels. In the presence of TTX, the $\mathrm{Ca}^{2+}$ responses were reduced by $88 \pm 2 \%$ SEM (Fig. $5 D, E$ ), indicating that opening of the L-type VGCCs was mostly caused by the membrane depolarizations associated with action potential firing.

\section{ipRGC $\mathrm{Ca}^{2+}$ dynamics during prolonged light stimuli}

The preceding data showed that most of the $\left[\mathrm{Ca}^{2+}\right]_{\mathrm{i}}$ elevation caused by a $20 \mathrm{~s}$ pulse of bright broad-spectrum light was the result of $\mathrm{Ca}^{2+}$ influx that occurred after action potential firing. We hypothesized that with a longer light pulse, we might unmask a more robust TTX-insensitive $\mathrm{Ca}^{2+}$ signal directly attributable to the channel mediating the initial depolarizing current (before cell spiking). The light exposure, of the same intensity as the $20 \mathrm{~s}$ pulse experiments, was increased to $4 \mathrm{~min}$ and fura- 2 fluorescence images were captured every $10 \mathrm{~s}$. Instead of sustaining a stable $\left[\mathrm{Ca}^{2+}\right]_{\mathrm{i}}$ throughout the $4 \mathrm{~min}$ light stimulus, the typical ipRGC showed a rise in $\left[\mathrm{Ca}^{2+}\right]_{\mathrm{i}}$ that peaked during the initial $20 \mathrm{~s}$ and then decayed to near baseline levels (Fig. $6 \mathrm{~A}$, black trace). In a minority of cells, a second increase in $\left[\mathrm{Ca}^{2+}\right]_{\mathrm{i}}$, followed by another decay to baseline, was observed during the $4 \mathrm{~min}$ (Fig. $6 A$, gray trace). Figure $6 B$ shows the mean data for $26 \mathrm{ipRGCs,}$ for which the $\mathrm{Ca}^{2+}$ response at the 24 time points was normalized to each cell's peak response. The peak $\mathrm{Ca}^{2+}$ response occurred at the $10 \mathrm{~s}$ time point in 12 of the 26 ipRGCs, and at $20 \mathrm{~s}$ after light onset in 10 of the remaining 14 cells. The small increase in the mean data around the $3 \mathrm{~min}$ time point (Fig. $6 \mathrm{~B}$ ) was attributable to the fact that 5 of the 26 ipRGCs displayed a second rise in the fura- 2 ratio ( $>50 \%$ of the peak response) around this time. The two response patterns illustrated in Figure $6 A$ likely do not represent distinct ipRGC subtypes, as both kinds of responses were sometimes elicited from individual cells (Fig. 6C, compare response 6 to responses 1 and 3$)$.

To perform fura- $2 \mathrm{Ca}^{2+}$ imaging during the 4 min light responses, it was necessary to periodically block off the halogen light stimulus to capture fura-2 images. Thus, at each $10 \mathrm{~s}$ interval, the broadspectrum light was off for $\sim 1 \mathrm{~s}$ for fura-2 image acquisition. To test whether this on-off feature of the light stimulus was the cause for the response decay, we determined whether collecting fura- 2 images every 40 or $80 \mathrm{~s}$ changed the characteristic pattern of the isolated ipRGC $\mathrm{Ca}^{2+}$ responses. As shown in Figure $6 C$, the interval between fura- 2 images did not influence the responses. By imaging every $40 \mathrm{~s}$ (response 4 ) or $80 \mathrm{~s}$ (response 5), the large rise in the fura- 2 ratio during the first $20 \mathrm{~s}$ of light onset (see responses $1,3,6)$ was missed but a similar pattern of response decay was observed as when a $10 \mathrm{~s}$ imaging strategy was used. Replotting a response that was obtained with $10 \mathrm{~s}$ interval imaging (response 3) using every fourth (40 s) or eighth ( $80 \mathrm{~s}$ ) data point yielded traces (Fig. 6C, two traces at far right) that were indistinguishable from those obtained with actual $40 \mathrm{~s}$ (response 4 ) or $80 \mathrm{~s}$ (response 5 ) imaging intervals. A decay in the $\mathrm{Ca}^{2+}$ response was also observed when the light stimulus was reduced with a $-1.5-\log$ neutral density filter, although this stimulus resulted in a smaller peak $\mathrm{Ca}^{2+}$ response (Fig. 6C, response 2).

Using a 4 min light stimulus and imaging every $10 \mathrm{~s}$, the vast majority of the response was still blocked by TTX (peak response reduced by $90.3 \pm 2.5 \%$ SEM; $n=8$ ipRGCs) (Fig. $6 D, E$ ). In five of these eight cells, the effect of a mixture containing both TTX and the TRPC channel blocker 2-APB was also assessed. Relative to the initial pretreatment response, TTX and 2-APB together abolished the light responses (peak response reduced by $99.2 \pm 0.4 \%$ SEM) (Fig. 6E). In all five cells, the $\mathrm{Ca}^{2+}$ responses were further reduced by the TTX plus 2 -APB mixture, compared with the responses obtained in the presence of TTX alone. Although these results suggest that $\mathrm{Ca}^{2+}$ flux through TRPC channels may contribute a small $(\sim 10 \%)$ amount to light-evoked changes in somal $\mathrm{Ca}^{2+}$ levels, these data corroborate those obtained using $20 \mathrm{~s}$ light pulses (Fig. $5 D, E$ ) signifying that most ( $\sim 90 \%$ ) of the light-stimulated rise in ipRGC somal $\left[\mathrm{Ca}^{2+}\right]_{\mathrm{i}}$ occurs after action potential firing.

To estimate the magnitude of the light-induced $\left[\mathrm{Ca}^{2+}\right]_{i}$ elevations, the minimum and maximum fura- 2 ratios were determined by exposing a separate group of ipRGCs $(n=9)$ to $\mathrm{Ca}^{2+}$-free and $\mathrm{Ca}^{2+}$-saturating conditions (see Materials and Methods). Calibration of the ratiometric data used to generate the normalized re- 
sponses shown in Figure $6 B(n=26$ ipRGCs) showed that the mean peak $\left[\mathrm{Ca}^{2+}\right]_{\mathrm{i}}$ reached during the 4 min light exposures was $517 \mathrm{nM}$ ( $\pm 65 \mathrm{SEM})$, which was an increase of $435 \mathrm{nM}$ from the mean baseline $\left[\mathrm{Ca}^{2+}\right]_{\mathrm{i}}$ of $82 \mathrm{nM}( \pm 5$ SEM). A similar conversion of the data in Figure $6 E$ indicated that the rise (peak minus baseline) in $\left[\mathrm{Ca}^{2+}\right]_{\mathrm{i}}$ that occurred with TTX present $(n=8$ ipRGCs) was $39 \mathrm{nM}( \pm 8$ SEM), whereas with TTX plus 2 -APB present $(n=$ $5)$ the change in $\left[\mathrm{Ca}^{2+}\right]_{\mathrm{i}}$ was only $4 \mathrm{nM}( \pm 3$ SEM).

\section{Concurrent $\mathrm{Ca}^{2+}$ imaging and cell- attached electrophysiological recordings of isolated ipRGC light responses}

With the pharmacological data supporting a link between ipRGC $\mathrm{Ca}^{2+}$ responses and action potential firing, we next investigated the relationship between ipRGC firing frequency and somatic $\left[\mathrm{Ca}^{2+}\right]_{\mathrm{i}} \mathrm{di}-$ rectly. As a related question, we sought to determine whether the $\mathrm{Ca}^{2+}$ response decay commonly observed during a $4 \mathrm{~min}$ light stimulus was caused by a decrease in cell firing during the light response. Alternatively, the decay could be unique to the $\mathrm{Ca}^{2+}$ response if, for example, the cause was VGCC desensitization. To address these issues, we combined $\mathrm{Ca}^{2+}$ imaging with patch-clamp electrophysiology, obtaining concurrent recordings of light responses from the isolated ipRGCs using both techniques.

Perforated patch-clamp recordings, performed alone (Fig. 7) and in conjunction with $\mathrm{Ca}^{2+}$ imaging (Fig. 7B), confirmed that isolated ipRGCs depolarized and fired action potentials in response to light exposure. To best probe the relationship between spike firing frequency and the magnitude of the $\mathrm{Ca}^{2+}$ responses, however, we used cell-attached patch recordings. The advantage of recording in cell-attached mode, relative to whole-cell or perforated patch-clamp configurations, is that it enabled an assessment of spike frequency in ipRGCs with intact membranes. Thus, it minimized the potential for the $\mathrm{Ca}^{2+}$ responses to be altered by cell dialysis.

The $\mathrm{Ca}^{2+}$ imaging data and the associated cell spiking activity of an ipRGC responding to a 4 min light stimulus, with fura-2 images acquired every $10 \mathrm{~s}$, is shown in Figure $8 \mathrm{~A}$. The peak fura-2 ratio (peak ratio, 1.92; baseline ratio, 0.72) occurred at $20 \mathrm{~s}$ after light onset. There were 102 spikes recorded in the $10 \mathrm{~s}$ interval before this peak $\mathrm{Ca}^{2+}$ response, and this was also the peak spike frequency recorded in the 24 different $10 \mathrm{~s}$ intervals during the 4 min light stimulus. Figure $8 B$ shows an expanded view of the same cell-attached recording depicted in Figure $8 \mathrm{~A}$. The time points denoted by numbers $1-4$ on the spike activity recording correspond to the time points denoted by matching numbers on the fura-2 optical trace. Note that as spike frequency increases
B

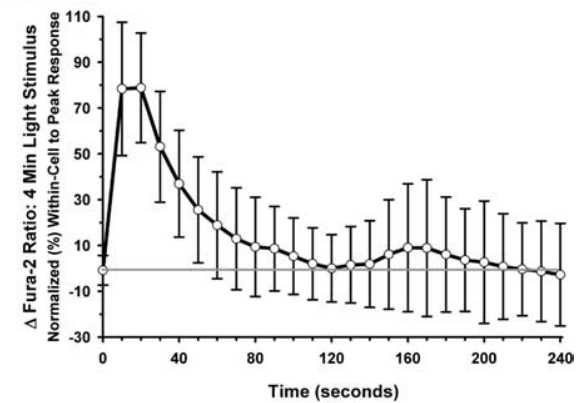

$\int_{8} \begin{aligned} & \text { Response } 3 \text { replotted using } \\ & \text { images acquired every } 80 \mathrm{~s}\end{aligned}$ \&o $\begin{aligned} & \text { Response } 3 \text { replotted using } \\ & \text { images acquired every } 40 \mathrm{~s}\end{aligned}$ $\overline{\mathrm{hv}}$
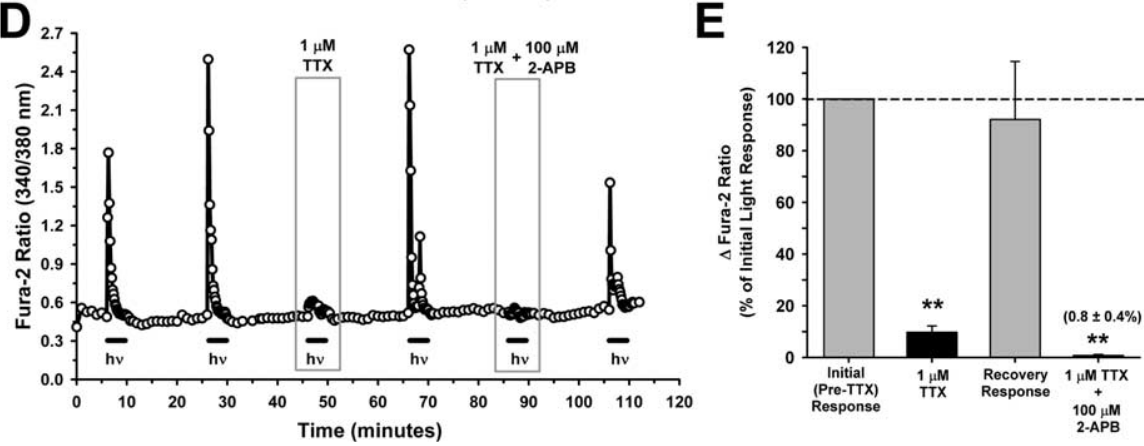

Figure 6. $\mathrm{Ca}^{2+}$ responses of ipRGCs exposed to light for $4 \mathrm{~min} . \boldsymbol{A}$, Recordings from two adjacent ipRGCs, exposed to the same light stimulus, exhibiting two distinct response patterns. For all traces (except second response in $[\mathrm{C}]$ ) $\mathrm{h} \nu$ indicates broadspectrum light, $6.9 \times 10^{13}$ photons $/ \mathrm{s} / \mathrm{cm}^{2}$ at $480 \mathrm{~nm}$. $\boldsymbol{B}$, Data summary (mean $\pm 1 \mathrm{SD} ; n=26$ ) illustrating the average decay in . For response 2, the standard stimulus intensity was reduced with a $-1.5 \log$ neutral density filter. During responses 4 and 5 , fura- 2 images were acquired every 40 and $80 \mathrm{~s}$, respectively. The traces at far right represent response 3 replotted using the fura- 2 ratios obtained every 40 or $80 \mathrm{~s}$ rather than $10 \mathrm{~s}$. $\boldsymbol{D}, \boldsymbol{E}$, Example trace $(\boldsymbol{D})$ and data summary (means \pm SEM, normalized to (E). TTX was tested in $8 \mathrm{ipRGCS}$, with 2-APB plus TTX subsequently tested in five of the eight cells. ${ }^{* *} p<0.01$, one-way repeatedmeasures ANOVA, Tukey's test, compared with initial responses.

(between points 1 and 2), there is a corresponding rise in the fura-2 ratio. Conversely, as spike frequency decreases (between points 3 and 4), ipRGC $\left[\mathrm{Ca}^{2+}\right]_{\mathrm{i}}$ also falls. Plotting each of the 25 fura- 2 ratios ( 24 ratios acquired during the 4 min light stimulation, plus 1 baseline ratio) for this cell against the number of spikes in the $10 \mathrm{~s}$ interval preceding each ratio (Fig. $8 \mathrm{C}$ ) revealed a highly linear relationship between the magnitude of the $\mathrm{Ca}^{2+}$ response and the cell spiking rate $\left(r^{2}=0.93\right)$.

Using this experimental paradigm, dual $\mathrm{Ca}^{2+}$ imaging and cell-attached recordings of light responses were obtained from 8 additional ipRGCs. The linear relationship between the fura- 2 ratio and the number of spikes in the $10 \mathrm{~s}$ interval that preceded each ratio was highly significant $(p<0.001$ for each of the nine cells; ANOVA), with values for the coefficient of determination $\left(r^{2}\right)$ that ranged between 0.66 and 0.93 (Fig. $8 D$, inset). The mean 

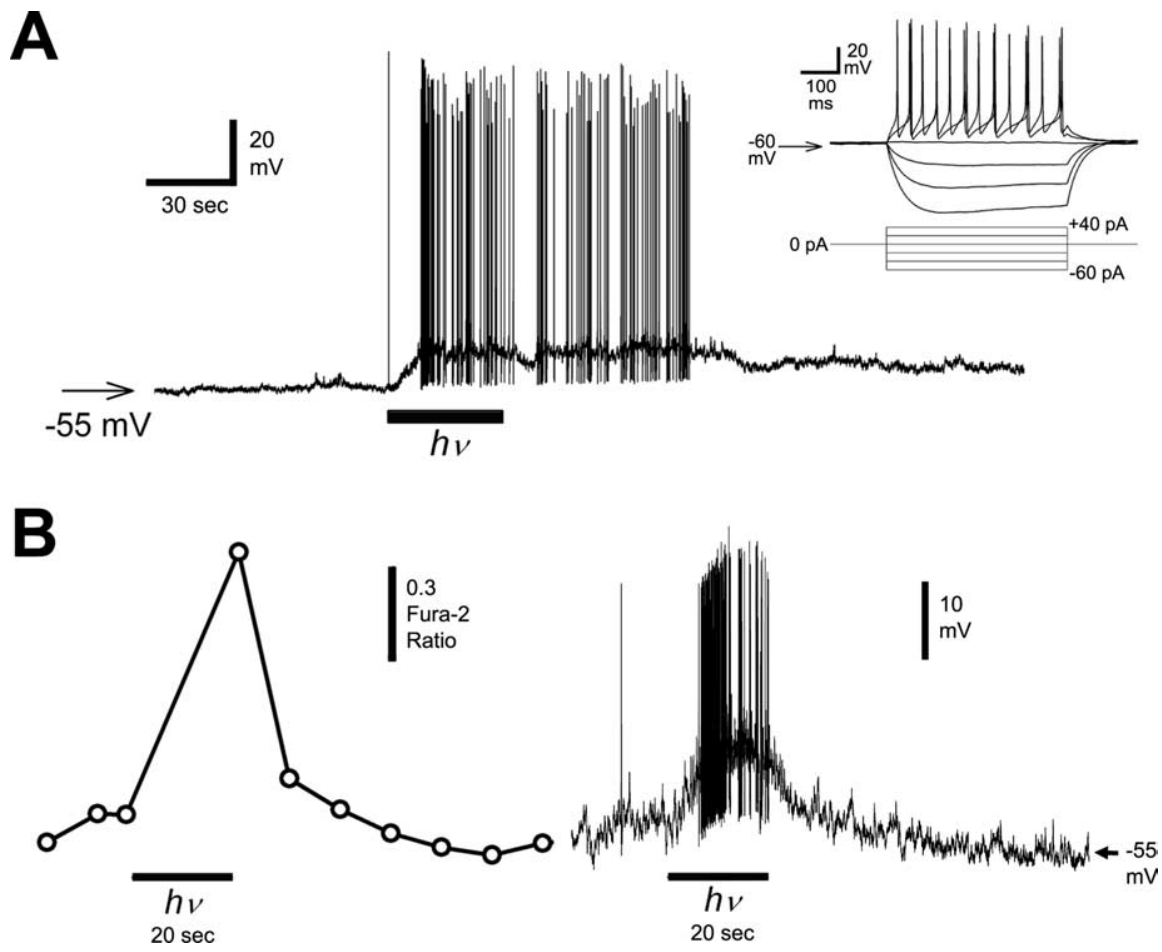

Figure 7. Light-induced depolarization and action potential firing in isolated ipRGCs.A, Perforated patch-clamp (current clamp mode) recording from ipRGC. Light (broad-spectrum, $2.9 \times 10^{14}$ photons $/ \mathrm{s} / \mathrm{cm}^{2}$ at $480 \mathrm{~nm}$ ) stimulated a slow depolarization (latency, $2 \mathrm{~s}$; speed, $1.1 \mathrm{mV} / \mathrm{s}$ ) that triggered spike firing (top trace). The initial spike is a stimulus artifact. The intrinsic electrophysiological properties of the cell (current steps, $500 \mathrm{~ms}$; ranging from $-60 \mathrm{pA}$ to $40 \mathrm{pA}$ in 6 steps) are displayed (inset). $\boldsymbol{B}$, Concurrent perforated patch-clamp recording and $\mathrm{Ca}^{2+}$ imaging trace obtained from an isolated ipRGC stimulated by light (broad-spectrum, $6.9 \times 10^{13}$ photons $/ \mathrm{s} / \mathrm{cm}^{2}$ at $480 \mathrm{~nm}$ ) for $20 \mathrm{~s}$. The recording in $A$ was recorded at room temperature $\left(\sim 25^{\circ} \mathrm{C}\right)$ whereas the external solution was warmed to $\sim 35^{\circ} \mathrm{C}$ for the recording in $\boldsymbol{B}$.

$r^{2}$ was 0.8 , indicating that $80 \%$ of the variability in the fura- 2 ratio over the 4 min light stimulus could, on average, be explained by the cell's spike frequency (based on $10 \mathrm{~s}$ bins of spike activity). In addition to the within-cell analyses, a significant linear relationship $\left(p<0.001\right.$, ANOVA; $\left.r^{2}=0.76\right)$ between the $\mathrm{Ca}^{2+}$ imaging data and the cell-attached recordings also existed when the 225 data points from all 9 cells were pooled together (Fig. $8 D$ ). Therefore, these data show that, in general, the ipRGCs displaying the largest light-evoked $\mathrm{Ca}^{2+}$ responses were also the cells that fired the most action potentials during the light stimulus.

\section{Discussion}

As a novel approach to the study of ipRGCs, we isolated these neurons from dissociated neonatal rat retinas into enriched cultures using melanopsin antibody-based immunopanning. Using this methodology, we provide the first recordings of ipRGC light responses using both $\mathrm{Ca}^{2+}$ imaging and patch-clamp techniques and demonstrate a direct link between $\left[\mathrm{Ca}^{2+}\right]_{\mathrm{i}}$ and action potential firing.

\section{Source of light-induced rise in ipRGC $\left[\mathrm{Ca}^{2+}\right]_{\mathrm{i}}$}

Three possibilities were considered for how increased $\left[\mathrm{Ca}^{2+}\right]_{\mathrm{i}}$ and spike firing might be interconnected within the ipRGC phototransduction cascade. First, these two response types could represent the culmination of two divergent pathways. This is the case for HEK cells that have been converted into photoreceptors by melanopsin transfection. In this heterologous system, TRPC3 channel overexpression was required for light-evoked membrane depolarization (Qiu et al., 2005), but light stimulated $\mathrm{Ca}^{2+}$ release from intracellular stores regardless of TRPC3 expression (Kumbalasiri et al., 2007). Second, ipRGC $\mathrm{Ca}^{2+}$ responses could precede action potential firing, as might be expected if $\mathrm{Ca}^{2+}$-permeable channels, including TRPC channels, mediate the initial depolarizing current. Finally, ipRGC $\mathrm{Ca}^{2+}$ responses may be a consequence of action potential firing and attributable to the depolarization-induced opening of VGCCs. Consistent with the latter two hypotheses, a previous study using isolated retinas from retinal degenerate mice reported an inhibitory effect for cadmium (blocker of VGCCs and many TRP channels) on ipRGC $\mathrm{Ca}^{2+}$ responses (Sekaran et al., 2003).

Of these three scenarios, our data support the last one as the predominant pathway by which light increases $\left[\mathrm{Ca}^{2+}\right]_{\mathrm{i}}$ in rat ipRGCs. Most $(\sim 90 \%)$ of the lightstimulated rise in $\left[\mathrm{Ca}^{2+}\right]_{i}$ could be inhibited by blocking action potentials with TTX, and concurrent $\mathrm{Ca}^{2+}$ imaging and cell-attached patch recordings demonstrated a high correlation between lightinduced spiking frequency and somatic $\left[\mathrm{Ca}^{2+}\right]_{\mathrm{i}}$. Furthermore, ipRGC Ca ${ }^{2+}$ responses were inhibited by the L-type VGCC blockers verapamil and diltiazem, but were unaffected by the internal $\mathrm{Ca}^{2+}$ stores depleting agent thapsigargin. Together, these results strongly support $\mathrm{Ca}^{2+}$ influx through L-type VGCCs as the primary source underlying light-evoked elevations in somatic $\left[\mathrm{Ca}^{2+}\right]_{\mathrm{i}}$, and indicate that VGCC activation follows action potential firing. The pathways underlying light-evoked $\mathrm{Ca}^{2+}$ influx in ipRGCs and their temporal relationship within the melanopsin phototransduction cascade is summarized in Figure 9.

\section{Role for TRPC channels?}

TRP channels mediate the light-gated current in Drosophila, and there has been considerable speculation that these channels are also involved in mammalian ipRGC phototransduction. To determine whether a member of the TRPC channel subfamily was an appropriate candidate, we tested a number of known TRPC channel blockers and found that 2-APB, SKF-96365, flufenamic acid, $\mathrm{La}^{3+}$, and $\mathrm{Gd}^{3+}$ all significantly inhibited the light-induced $\mathrm{Ca}^{2+}$ responses of the isolated ipRGCs. These results are, for the most part, similar to the findings of two previous reports in which various TRPC channel blockers reduced ipRGC light responses in whole-retina preparations from adult rats (patch-clamp recordings) (Warren et al., 2006) and neonatal mice $\left(\mathrm{Ca}^{2+}\right.$ imaging) (Sekaran et al., 2007). Unfortunately, pharmacology alone cannot conclusively identify a TRPC channel, as known blockers are nonselective and inhibit a myriad of cation channels. Narrowing our search to TRPC3, TRPC6, and TRPC7, we detected message for each of these channels in the melanopsin-panned cultures. These data bolster previous immunocytochemical evidence localizing TRPC6 and TRPC7 to melanopsin-expressing RGCs (Warren et al., 2006; Sekaran et al., 2007). It also suggests that, like many neurons, ipRGCs likely contain multiple TRP channel subunits, raising the possibility that the light-gated channel is heteromeric. Interestingly, our PCR data showed a preferential expression of TRPC7 in melanopsin-panned cultures relative to 
Thy1-panned RGC cultures. Although definitive identification of the ipRGC lightgated channel will probably require genetic approaches, our pharmacological and PCR data endorse TRPC channels, especially TRPC7, as prime candidates.

Because VGCCs are present in conventional RGCs, it is perhaps not unexpected that VGCC-mediated $\mathrm{Ca}^{2+}$ influx also occurs in the more rare ipRGCs. However, it was surprising that, after action potential blockade, the remaining $\mathrm{Ca}^{2+}$ responses were so minimal. Our results support an additive effect for 2-APB with TTX, consistent with TRPC channel involvement, but the light-induced $\mathrm{Ca}^{2+}$ signal that was elicited with TTX present approached signal-to-noise limitations. One possibility for this finding is that the light-gated channel may be more permeable to $\mathrm{Na}^{+}$ relative to $\mathrm{Ca}^{2+}$. Previous data argues against this because removal of extracellular $\mathrm{Na}^{+}$does not significantly alter lightstimulated currents in voltage-clamped rat ipRGCs (Warren et al., 2003). Another plausible hypothesis is that most of the $\mathrm{Ca}^{2+}$ passing through the light-gated channel may not reach the ipRGC soma. For example, Drosophila TRP channels are closely associated with scaffolding and other proteins in a structure termed a "signalplex," and there is accumulating evidence that mammalian TRPC channels form similar membrane-bound complexes (Ambudkar et al., 2006). These complexes provide $\mathrm{Ca}^{2+}$ signaling microdomains that are spatially segregated from the somatic cytoplasm, allowing more precise regulation of $\mathrm{Ca}^{2+}$ dependent processes within the microdomain. If a similar TRPC signalplex exists in ipRGCs, $\mathrm{Ca}^{2+}$ influx through these channels may not have the same access to the soma as VGCC-mediated $\mathrm{Ca}^{2+}$ entry. Finally, it should be noted that the membrane depolarization induced by the initial $\mathrm{Ca}^{2+}$ influx could also be amplified through the activation of $\mathrm{Ca}^{2+}$-activated chloride currents. In other sensory neurons, such as those involved in olfactory transduction, $\mathrm{Ca}^{2+}$-activated chloride efflux is a major component of the depolarizing current (Lowe and Gold, 1993).

\section{Photoresponses of melanopsin-immunopanned RGCs}

The present study establishes the feasibility of using an immunopanning approach to generate enriched cultures of melanopsinexpressing ipRGCs. Like conventional RGCs, melanopsinpanned ipRGCs expressed Thyl and responded to glutamate stimulation. As illustrated throughout this work, multiple and repeatable light responses could be elicited from the isolated ipRGCs over the first few days of culture. However, in cultures maintained for longer periods, a reduction in melanopsin expression and an accompanying loss of photosensitivity was apparent. The reason is not yet known, but there is evidence from rat models of rod/cone degeneration that melanopsin transcription is dependent on the presence of these classical photoreceptors (Sakamoto et al., 2004; Wan et al., 2006) (but see Semo et al., 2003). Immunopanned ipRGCs should therefore provide an in vitro system in which to test whether certain retinal- or SCNderived factors are involved in regulating melanopsin expression.

In some ipRGCs, light responses were reduced if consecutive light pulses were spaced too closely together. Also, $\mathrm{Ca}^{2+}$ responses exhibited a characteristic decay during prolonged $4 \mathrm{~min}$ light stimuli. On the surface, these findings are puzzling given that, in vivo, these neurons provide the photic information that synchronizes SCN-driven circadian rhythms to the external day/ night environment. The observed response decay was not caused by VGCC desensitization, or another process unique to the $\mathrm{Ca}^{2+}$ signal, as indicated by the linear correlation between $\left[\mathrm{Ca}^{2+}\right]_{\mathrm{i}}$ and spiking frequency throughout the $4 \mathrm{~min}$ light stimuli. One possibility is that the response decay was caused by chromophore depletion (bleaching). Because photoresponsiveness was recoverable, a corollary to this hypothesis is that ipRGCs can regener- 


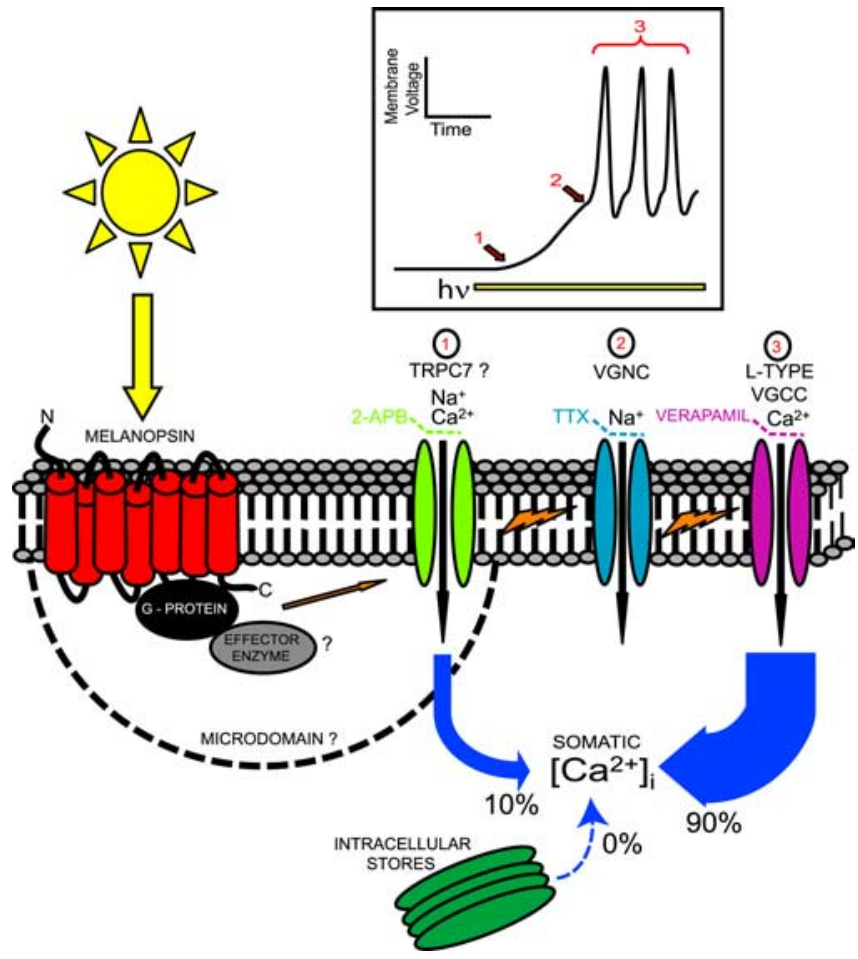

Figure 9. Schematic overview of light-evoked $\mathrm{Ca}^{2+}$ influx in mammalian ipRGCs. After light stimulation of melanopsin photopigment in the plasma membrane, a signaling cascade is initiated that leads to the opening of the light-gated ion channel (labeled 1). This cascade remains almost completely unknown, although there is evidence that it is G-protein dependent (Warren et al., 2006) and that protein kinase $(\zeta$ is involved (Peirson et al., 2007). The data presented in this work and that of others (Warren et al., 2006; Sekaran et al., 2007) supports the hypothesis that a TRPC channel is the light-gated ion channel, with our data supporting TRPC7 as a prime candidate. The ion flux through this 2-APB-sensitive channel depolarizes (denoted with a lightning bolt in the membrane) the membrane potential, resulting in the activation of voltagegated $\mathrm{Na}^{+}$channels (VGNCs; labeled 2). The $\mathrm{Na}^{+}$flux through TTX-sensitive VGNCs during action potential firing further depolarizes the membrane, leading to the activation of verapamil-sensitive L-type VGCCs (labeled 3). The relative timing for the opening of these three channel types is illustrated in the boxed drawing that depicts the changes in membrane voltage induced by light exposure in a typical ipRGC. Although our work indicates that $\mathrm{Ca}^{2+}$ influx through the initial light-gated ion channel contributes to increased somatic $\left[\mathrm{Ca}^{2+}\right]_{\mathrm{i}}$ during light stimulation, most of the $\mathrm{Ca}^{2+}$ signal was the result of the depolarization-induced opening of VGCCs. The presence of a membrane-associated microdomain that prevents some of the $\mathrm{Ca}^{2+}$ flux through the light-gated channel from reaching the somatic cytoplasm is also possible. Experiments involving the stores depleting agent thapsigargin indicated that contribution of intracellular $\mathrm{Ca}^{2+}$ stores to light-evoked elevations in ipRGC $\left[\mathrm{Ca}^{2+}\right]_{\mathrm{i}}$ was negligible.

ate bleached chromophore back to light-sensitive conformations. Chromophore regeneration occurs in invertebrate photoreceptors and there is indirect evidence that this process exists in mammalian ipRGCs (Doyle et al., 2006; Tu et al., 2006). However, rather than chromophore bleaching, the pattern of response decay may instead reflect an active adaptation to the constantintensity light stimulus. In support, patch-clamp recordings of rat ipRGCs in intact retinas indicate that these photoreceptors do exhibit both light and dark adaptation (Wong et al., 2005).

$\mathrm{Ca}^{2+}$ is a key intracellular messenger that, among its many functions, modulates neuronal output by regulating the activation of potassium channels (Sah and Faber, 2002). In considering other potential functions associated with VGCC-mediated $\mathrm{Ca}^{2+}$ influx, a role in ipRGC adaptation might be expected as $\mathrm{Ca}^{2+}$ provides the feedback that initiates adaptation mechanisms in vertebrate rods/cones (Krizaj and Copenhagen, 2002) and Drosophila photoreceptors (Gu et al., 2005). In addition, $\mathrm{Ca}^{2+}$ influx via L-type VGCCs contributes to neuronal plasticity in many CNS neurons by coupling excitation to the activation of genes such as $c$-fos (Murphy et al., 1991; Thompson et al., 1995). Lightinduced Fos protein expression has been observed in melanopsin RGCs in mice lacking rods and cones (Semo et al., 2003), and so the light-evoked alterations in $\left[\mathrm{Ca}^{2+}\right]_{\mathrm{i}}$ could regulate ipRGC gene expression in response to cell activity.

A major advantage of melanopsin-based immunopanning is that it enables the study of solitary ipRGCs. In addition to their intrinsic photosensitivity, melanopsin-expressing RGCs receive synaptic input from retinal bipolar and amacrine cells (Belenky et al., 2003; Dacey et al., 2005; Perez-Leon et al., 2006; Ostergaard et al., 2007; Viney et al., 2007; Wong et al., 2007), and may be electrically coupled to other inner retinal neurons via gap junctions (Sekaran et al., 2003). Isolating ipRGCs into enriched cultures therefore eliminates all extrinsic modulatory influences on the intrinsic light responses that occur in the intact retina, and negates the need for pharmacological blockade of synaptic activity. Much of the ipRGC phototransduction cascade remains unknown (Fig. 9), and enriched cultures of immunopanned ipRGCs should serve as a useful preparation for future physiological, molecular and biochemical characterizations of melanopsin-related signaling pathways.

\section{References}

Ambudkar IS, Bandyopadhyay BC, Liu X, Lockwich TP, Paria B, Ong HL (2006) Functional organization of TRPC-Ca ${ }^{2+}$ channels and regulation of calcium microdomains. Cell Calcium 40:495-504.

Barres BA, Silverstein BE, Corey DP, Chun LL (1988) Immunological, morphological, and electrophysiological variation among retinal ganglion cells purified by panning. Neuron 1:791-803.

Belenky MA, Smeraski CA, Provencio I, Sollars PJ, Pickard GE (2003) Melanopsin retinal ganglion cells receive bipolar and amacrine cell synapses. J Comp Neurol 460:380-393.

Berson DM (2007) Phototransduction in ganglion-cell photoreceptors. Pflugers Arch 454:849-855.

Berson DM, Dunn FA, Takao M (2002) Phototransduction by retinal ganglion cells that set the circadian clock. Science 295:1070-1073.

Catterall WA, Perez-Reyes E, Snutch TP, Striessnig J (2005) International Union of Pharmacology. XLVIII. Nomenclature and structure-function relationships of voltage-gated calcium channels. Pharmacol Rev 57:411-425.

Dacey DM, Liao HW, Peterson BB, Robinson FR, Smith VC, Pokorny J, Yau KW, Gamlin PD (2005) Melanopsin-expressing ganglion cells in primate retina signal colour and irradiance and project to the LGN. Nature 433:749-754.

Doyle SE, Castrucci AM, McCall M, Provencio I, Menaker M (2006) Nonvisual light responses in the Rpe65 knock-out mouse: rod loss restores sensitivity to the melanopsin system. Proc Natl Acad Sci USA 103:10432-10437.

Gooley JJ, Lu J, Fischer D, Saper CB (2003) A broad role for melanopsin in nonvisual photoreception. J Neurosci 23:7093-7106.

Gu Y, Oberwinkler J, Postma M, Hardie RC (2005) Mechanisms of light adaptation in Drosophila photoreceptors. Curr Biol 15:1228-1234.

Halaszovich CR, Zitt C, Jungling E, Luckhoff A (2000) Inhibition of TRP3 channels by lanthanides. Block from the cytosolic side of the plasma membrane. J Biol Chem 275:37423-37428.

Hannibal J, Fahrenkrug J (2004a) Target areas innervated by PACAPimmunoreactive retinal ganglion cells. Cell Tissue Res 316:99-113.

Hannibal J, Fahrenkrug J (2004b) Melanopsin containing retinal ganglion cells are light responsive from birth. NeuroReport 15:2317-2320.

Hartwick AT, Lalonde MR, Barnes S, Baldridge WH (2004) Adenosine A1receptor modulation of glutamate-induced calcium influx in rat retinal ganglion cells. Invest Ophthalmol Vis Sci 45:3740-3748.

Hartwick AT, Zhang X, Chauhan BC, Baldridge WH (2005) Functional assessment of glutamate clearance mechanisms in a chronic rat glaucoma model using retinal ganglion cell calcium imaging. J Neurochem 94:794-807.

Hattar S, Liao HW, Takao M, Berson DM, Yau KW (2002) Melanopsin- 
containing retinal ganglion cells: architecture, projections, and intrinsic photosensitivity. Science 295:1065-1070.

Hattar S, Lucas RJ, Mrosovsky N, Thompson S, Douglas RH, Hankins MW, Lem J, Biel M, Hofmann F, Foster RG, Yau KW (2003) Melanopsin and rod-cone photoreceptive systems account for all major accessory visual functions in mice. Nature 424:76-81.

Hattar S, Kumar M, Park A, Tong P, Tung J, Yau KW, Berson DM (2006) Central projections of melanopsin-expressing retinal ganglion cells in the mouse. J Comp Neurol 497:326-349.

Inoue R, Okada T, Onoue H, Hara Y, Shimizu S, Naitoh S, Ito Y, Mori Y (2001) The transient receptor potential protein homologue TRP6 is the essential component of vascular alpha(1)-adrenoceptor-activated $\mathrm{Ca}^{2+}$. permeable cation channel. Circ Res 88:325-332.

Jakobs TC, Ben Y, Masland RH (2007) Expression of mRNA for glutamate receptor subunits distinguishes the major classes of retinal neurons, but is less specific for individual cell types. Mol Vis 13:933-948.

Jung S, Muhle A, Schaefer M, Strotmann R, Schultz G, Plant TD (2003) Lanthanides potentiate TRPC 5 currents by an action at extracellular sites close to the pore mouth. J Biol Chem 278:3562-3571.

Kao JP (1994) Practical aspects of measuring $\left[\mathrm{Ca}^{2+}\right]$ with fluorescent indicators. Methods Cell Biol 40:155-181.

Karschin A, Lipton SA (1989) Calcium channels in solitary retinal ganglion cells from post-natal rat. J Physiol (Lond) 418:379-396.

Krizaj D, Copenhagen DR (2002) Calcium regulation in photoreceptors. Front Biosci 7:d2023-d2044.

Kumbalasiri T, Rollag MD, Isoldi M, de Lauro Castrucci AM, Provencio I (2007) Melanopsin triggers the release of internal calcium stores in response to light. Photochem Photobiol 83:273-280.

Leinders-Zufall T, Rand MN, Waxman SG, Kocsis JD (1994) Differential role of two $\mathrm{Ca}^{2+}$-permeable non-NMDA glutamate channels in rat retinal ganglion cells: kainate-induced cytoplasmic and nuclear $\mathrm{Ca}^{2+}$ signals. J Neurophysiol 72:2503-2516.

Lewis RS (2007) The molecular choreography of a store-operated calcium channel. Nature 446:284-287.

Lowe G, Gold GH (1993) Nonlinear amplification by calcium-dependent chloride channels in olfactory receptor cells. Nature 366:283-286.

Meyer-Franke A, Kaplan MR, Pfrieger FW, Barres BA (1995) Characterization of the signaling interactions that promote the survival and growth of developing retinal ganglion cells in culture. Neuron 15:805-819.

Minke B, Parnas M (2006) Insights on TRP channels from in vivo studies in Drosophila. Annu Rev Physiol 68:649-684.

Morin LP, Blanchard JH, Provencio I (2003) Retinal ganglion cell projections to the hamster suprachiasmatic nucleus, intergeniculate leaflet, and visual midbrain: bifurcation and melanopsin immunoreactivity. J Comp Neurol 465:401-416.

Murphy TH, Worley PF, Baraban JM (1991) L-type voltage-sensitive calcium channels mediate synaptic activation of immediate early genes. Neuron 7:625-635.

Ostergaard J, Hannibal J, Fahrenkrug J (2007) Synaptic contact between melanopsin-containing retinal ganglion cells and rod bipolar cells. Invest Ophthalmol Vis Sci 48:3812-3820.

Panda S, Provencio I, Tu DC, Pires SS, Rollag MD, Castrucci AM, Pletcher MT, Sato TK, Wiltshire T, Andahazy M, Kay SA, Van Gelder RN, Hogenesch JB (2003) Melanopsin is required for non-image-forming photic responses in blind mice. Science 301:525-527.

Peirson S, Foster RG (2006) Melanopsin: another way of signaling light. Neuron 49:331-339.

Peirson SN, Oster H, Jones SL, Leitges M, Hankins MW, Foster RG (2007) Microarray analysis and functional genomics identify novel components of melanopsin signaling. Curr Biol 17:1363-1372.

Perez-Leon JA, Warren EJ, Allen CN, Robinson DW, Lane Brown R (2006) Synaptic inputs to retinal ganglion cells that set the circadian clock. Eur J Neurosci 24:1117-1123.

Provencio I, Jiang G, De Grip WJ, Hayes WP, Rollag MD (1998) Melanopsin: an opsin in melanophores, brain, and eye. Proc Natl Acad Sci USA 95:340-345.

Qiu X, Kumbalasiri T, Carlson SM, Wong KY, Krishna V, Provencio I, Berson
DM (2005) Induction of photosensitivity by heterologous expression of melanopsin. Nature 433:745-749.

Ramsey IS, Delling M, Clapham DE (2006) An introduction to TRP channels. Annu Rev Physiol 68:619-647.

Reuss H, Mojet MH, Chyb S, Hardie RC (1997) In vivo analysis of the drosophila light-sensitive channels, TRP and TRPL. Neuron 19:1249-1259.

Riccio A, Mattei C, Kelsell RE, Medhurst AD, Calver AR, Randall AD, Davis JB, Benham CD, Pangalos MN (2002) Cloning and functional expression of human short TRP7, a candidate protein for store-operated $\mathrm{Ca}^{2+}$ influx. J Biol Chem 277:12302-12309.

Sah P, Faber ES (2002) Channels underlying neuronal calcium-activated potassium currents. Prog Neurobiol 66:345-353.

Sakamoto K, Liu C, Tosini G (2004) Classical photoreceptors regulate melanopsin mRNA levels in the rat retina. J Neurosci 24:9693-9697.

Schaefer M, Plant TD, Obukhov AG, Hofmann T, Gudermann T, Schultz G (2000) Receptor-mediated regulation of the nonselective cation channels TRPC4 and TRPC5. J Biol Chem 275:17517-17526.

Schmid S, Guenther E (1999) Voltage-activated calcium currents in rat retinal ganglion cells in situ: changes during prenatal and postnatal development. J Neurosci 19:3486-3494.

Sekaran S, Foster RG, Lucas RJ, Hankins MW (2003) Calcium imaging reveals a network of intrinsically light-sensitive inner-retinal neurons. Curr Biol 13:1290-1298.

Sekaran S, Lupi D, Jones SL, Sheely CJ, Hattar S, Yau KW, Lucas RJ, Foster RG, Hankins MW (2005) Melanopsin-dependent photoreception provides earliest light detection in the mammalian retina. Curr Biol 15:1099-1107.

Sekaran S, Lall GS, Ralphs KL, Wolstenholme AJ, Lucas RJ, Foster RG, Hankins MW (2007) 2-Aminoethoxydiphenylborane is an acute inhibitor of directly photosensitive retinal ganglion cell activity in vitro and in vivo. J Neurosci 27:3981-3986.

Semo M, Lupi D, Peirson SN, Butler JN, Foster RG (2003) Light-induced c-fos in melanopsin retinal ganglion cells of young and aged rodless/ coneless ( $\mathrm{rd} / \mathrm{rd} \mathrm{cl}$ ) mice. Eur J Neurosci 18:3007-3017.

Sollars PJ, Smeraski CA, Kaufman JD, Ogilvie MD, Provencio I, Pickard GE (2003) Melanopsin and non-melanopsin expressing retinal ganglion cells innervate the hypothalamic suprachiasmatic nucleus. Vis Neurosci 20:601-610.

Thompson MA, Ginty DD, Bonni A, Greenberg ME (1995) L-type voltagesensitive $\mathrm{Ca}^{2+}$ channel activation regulates c-fos transcription at multiple levels. J Biol Chem 270:4224-4235.

Treiman M, Caspersen C, Christensen SB (1998) A tool coming of age: thapsigargin as an inhibitor of sarco-endoplasmic reticulum $\mathrm{Ca}^{2+}$. ATPases. Trends Pharmacol Sci 19:131-135.

Tu DC, Owens LA, Anderson L, Golczak M, Doyle SE, McCall M, Menaker M, Palczewski K, Van Gelder RN (2006) Inner retinal photoreception independent of the visual retinoid cycle. Proc Natl Acad Sci USA 103:10426-10431.

Verkhratsky A (2005) Physiology and pathophysiology of the calcium store in the endoplasmic reticulum of neurons. Physiol Rev 85:201-279.

Viney TJ, Balint K, Hillier D, Siegert S, Boldogkoi Z, Enquist LW, Meister M, Cepko CL, Roska B (2007) Local retinal circuits of melanopsincontaining ganglion cells identified by transsynaptic viral tracing. Curr Biol 17:981-988.

Wan J, Zheng H, Hu BY, Xiao HL, She ZJ, Chen ZL, Zhou GM (2006) Acute photoreceptor degeneration down-regulates melanopsin expression in adult rat retina. Neurosci Lett 400:48-52.

Warren EJ, Allen CN, Brown RL, Robinson DW (2003) Intrinsic light responses of retinal ganglion cells projecting to the circadian system. Eur J Neurosci 17:1727-1735.

Warren EJ, Allen CN, Brown RL, Robinson DW (2006) The light-activated signaling pathway in SCN-projecting rat retinal ganglion cells. Eur J Neurosci 23:2477-2487.

Wong KY, Dunn FA, Berson DM (2005) Photoreceptor adaptation in intrinsically photosensitive retinal ganglion cells. Neuron 48:1001-1010.

Wong KY, Dunn FA, Graham DM, Berson DM (2007) Synaptic influences on rat ganglion-cell photoreceptors. J Physiol (Lond) 582:279-296. 